\title{
Brain-Site-Specific Proteome Changes Induced by Neuronal P60TRP Expression
}

\author{
Arulmani Manavalan ${ }^{a, b}$ Manisha Mishra ${ }^{a} b \quad$ Siu Kwan Sze ${ }^{a}$ Klaus Heese $^{c}$ \\ ${ }^{a}$ School of Biological Sciences and ${ }^{b}$ Institute of Advanced Studies, Nanyang Technological University, \\ Singapore, Singapore; ' Department of Biomedical Engineering, Hanyang University, Seoul, Korea
}

\section{Key Words}

p60 transcription regulator protein $\cdot$ Brain $\cdot$ Cortex .

GPRASP $\cdot$ Hippocampus $\cdot$ Metabolism

\begin{abstract}
p60 transcription regulator protein (p60TRP) facilitates the processing of the amyloid precursor protein towards the non-amyloidogenic pathway by inhibiting the $\beta$-secretase action. This protein was initially identified to be downregulated in the temporal lobe of brains from Alzheimer's disease patients. p60TRP is one of the G-protein-coupled receptor (GPCR)-associated proteins which directly influences the signalling capacity of GPCRs. In the present study, we investigated the brain-region-specific proteome profile of transgenic p60TRP mice to gain an insight into the molecular events mediated by the long-term effect of neuronal p60TRP overexpression on brain proteome changes and its potential implication for neuronal functions in the central nervous system. Using a proteomics research approach based on isobaric tags for relative and absolute quantitation, we identified 2,025 proteins, whereby 1,735 proteins were quantified, out of which 56 were found to be significantly altered in the cortex and/or hippocampus of neuronal transgenic neuronal p60TRP mice. Our data suggests that in vivo overexpression of neuronal p60TRP significantly affects cognitive and neuroprotective capacities. Copyright $\odot 2013 \mathrm{~S}$. Karger AG, Basel
\end{abstract}

\begin{tabular}{ll}
\hline KARGER & $\begin{array}{l}\text { ( } 2013 \text { S. Karger AG, Basel } \\
1424-862 X / 13 / 0214-0129 \$ 38.00 / 0 \quad \text { Karger }\end{array}$ \\
$\begin{array}{l}\text { E-Mail karger@karger.com } \\
\text { www.karger.com/ng }\end{array}$ & $\begin{array}{l}\text { This is an Open Access article licensed under the terms of the } \\
\text { Creative Commons Attribution-NonCommercial 3.0 Un- } \\
\text { ported license (CC BY-NC) (www.karger.com/OA-license), } \\
\text { applicable to the online version of the article only. Distribu- } \\
\text { tion permitted for non-commercial purposes only. }\end{array}$
\end{tabular}

\section{Introduction}

G-protein-coupled receptors (GPCRs) represent one of the most abundant protein families that are involved in the modulation of numerous physiological functions thus represent major drug targets. The activity of GPCRs is tightly controlled by various interacting partners that modulate their membrane targeting, intracellular trafficking and signalling properties. One of the ways in which their activity is regulated is by the process of desensitisation and endocytosis, whereby agonist-activated receptors are rapidly and often reversibly silenced through removal from the cell surface. Following endocytosis, individual receptors can be sorted differentially between recycling endosomes and lysosomes, which control the reversibility of silencing. Thus, endocytosis can either serve as a mechanism for receptor resensitisation by delivering receptors back to the plasma membrane or facilitate receptor downregulation by serving as the first step towards targeting the receptors to lysosomal degradation. The sorting of receptors to the lysosomal pathway can be facilitated by interaction with an array of accessory proteins. Among them, the GPCR-associated sorting proteins (GPRASPs) have been shown to display a

\section{A.M. and M.M. contributed equally to this study.}


broad spectrum of interactions with GPCRs. In recent years, extensive research has identified and categorized numerous interacting partners of GPCRs and revealed the GPRASP family $[1,2]$. In addition to their postulated role in the modulation of the postendocytic sorting of these receptors, recent data indicate that some of the GPRASP family members may modulate the transcriptional activity of the cell. The p60 transcription regulator protein (p60TRP), also known as GASP3 or BHLHB9, is one novel member of this recently discovered GPRASP family $[3,4]$. Amongst the many distinguishing features of p60TRP it is noteworthy that it contains a myc-type bHLH-like domain at its $\mathrm{C}$ terminus which is a protein structural motif that characterizes transcription factors. Our studies have also shown that p60TRP regulates endocytic recycling of the $\delta$-opioid receptor and is a predominant nervous system-associated protein that localizes to both the cytoplasm and the nucleus of cells $[3,4]$.

Our newly established transgenic p60TRP mice consistently revealed a tendency to repair Alzheimer's disease (AD)-related deficits by facilitating the proteolytic cleavage of the amyloid precursor protein towards the non-amyloidogenic pathway, higher synaptic plasticity as well as cognitive functions [4]. We applied the 2-dimensional (2D) liquid chromatography coupled with tandem mass spectrometry-based isobaric tag for relative and absolute quantification (2D-LC-MS/MS iTRAQ) technique into our clinically relevant in vivo mouse model for quantitative profiling of p60TRP-regulated brain-region-specific genes. Subsequently, we generated the proteome comprising the regulated proteins from the transgenic p60TRP mouse-derived brain (fig. 1). Our results show for the first time the long-term in vivo effect of neuronal p60TRP overexpression on brain-region-specific proteome changes and its potential implication for brain functions.

\section{Materials and Methods}

\section{Reagents}

Unless indicated, all reagents used for biochemical methods were purchased from Sigma-Aldrich (St. Louis, Mo., USA). Materials and reagents for SDS-PAGE (sodium dodecyl sulphate-polyacrylamide gel electrophoresis) were from Bio-Rad (Bio-Rad Laboratories, Hercules, Calif., USA). The iTRAQ reagent multiplex kit was bought commercially (Applied Biosystems, Foster City, Calif., USA).

\section{Antibodies}

Anti-Acadl (acyl-coenzyme A dehydrogenase, long-chain, 1:1,000, rabbit polyclonal; Abcam, Cambridge, UK), anti-Gapdh (glyceraldehyde-3-phosphate dehydrogenase, 1:3,000, mouse monoclonal; Santa Cruz Biotechnology Inc., Santa Cruz, Calif., USA), anti-Mbp (myelin basic protein, 1:200, rat monoclonal; Abcam), anti-Mtap2 (microtubule-associated protein 2, 1:1,000, rabbit polyclonal; Abcam), anti-Sept2 (septin 2, 1:200, goat polyclonal; Santa Cruz Biotechnology), anti-Snca [synuclein $(\alpha)$, 1:1,000, mouse monoclonal; Santa Cruz Biotechnology], antiSncb (synuclein ( $\beta$ ), 1:1,000, mouse monoclonal; Santa Cruz Biotechnology), anti-Sod1 (superoxide dismutase 1, 1:1,500, rabbit polyclonal; Abcam), anti-Synj1 (synaptojanin 1, polyphosphoinositide phosphatase, 1:1,000, rabbit polyclonal, mouse monoclonal; BD Biosciences, Clontech, Palo Alto, Calif., USA) and anti-Tuba8 (tubulin, $\alpha_{8}, 1: 2,000$, mouse monoclonal; Abcam).

\section{Animal Material}

Experimental procedures, including the killing of animals, were in accordance with the International Guiding Principles for Animal Research (World Health Organization) and were approved by the local Institutional Animal Care and Use Committee (Nanyang Technological University Institutional Animal Care and Use Committee). Throughout all protocols, mice were provided with food and water ad libitum and maintained in controlled conditions (12-hour light-dark cycle, $25^{\circ} \mathrm{C}$ ). All offspring were weaned onto standard chow at 21 days of age, and metabolic tissue parameters were assessed at 18 months of age. Mouse tissues, i.e. from p60TRP transgenic mice [4] and control wild-type litter mates (C57BL/6J), were isolated after humane killing of the animals using approved anaesthetic methods. To analyse the tissue-specific protein expression, all efforts were made to minimize animal suffering and to reduce the number of animals used $[4,5]$.

\section{Brain-Tissue-Specific Protein Expression Analysis}

Brain tissues (cortex $(\mathrm{Cx})$ and hippocampus ( $\mathrm{Hp})$ ) were isolated from adult (approx. 18 months) transgenic p60TRP mice and wild-type litter mates (each group consisting of 3 males and 3 females, i.e. 6 mice) from each mouse strain $\operatorname{tg} 38$ and $\operatorname{tg} 31$, for both batches B-I and B-II, respectively (fig. 1). Briefly, tissues were excised, snap-frozen in liquid nitrogen, and then powdered using

Fig. 1. Schematic representation of the experimental design showing biological and technical replicates. Brain tissues were isolated from adult (approx. 18 months) transgenic p60TRP mice (tg) and wild-type litter mates (wt), each group (B-I and B-II) consisting of 3 males and 3 females, separately for each brain area ( $\mathrm{Cx}$ and $\mathrm{Hp})$ and for each mouse strain (tg38 and tg31); for B-I: $6 \operatorname{tg} 31 \mathrm{Cx}$ and $6 \operatorname{tg} 31 \mathrm{Hp}, 6 \operatorname{tg} 38 \mathrm{Cx}$ and $6 \operatorname{tg} 38 \mathrm{Hp}, 6$ wt $\mathrm{Cx}$ and 6 wt Hp; for B-II: $6 \operatorname{tg} 31 \mathrm{Cx}$ and $6 \operatorname{tg} 31 \mathrm{Hp}, 6 \operatorname{tg} 38 \mathrm{Cx}$ and $6 \operatorname{tg} 38 \mathrm{Hp}, 6$ wt Cx and $6 \mathrm{wt} \mathrm{Hp}$. Following brain-derived tissue lysis, protein extracts were acetone precipitated, quantified, run on SDS-PAGE and subsequently digested. The quantitative proteomics analyses of transgenic p60TRP mouse-derived brains were performed by labelling with multiplex iTRAQ reagents (113-118) followed by electrostatic repulsion-hydrophilic interaction chromatography (ERLIC)-based fractionation, and LC-MS/MS-based multidimensional protein identification technology. The obtained data was analysed using ProteinPilot software and validated by quantitative Western blots. Finally, proteins were functionally classified into various subgroups. 


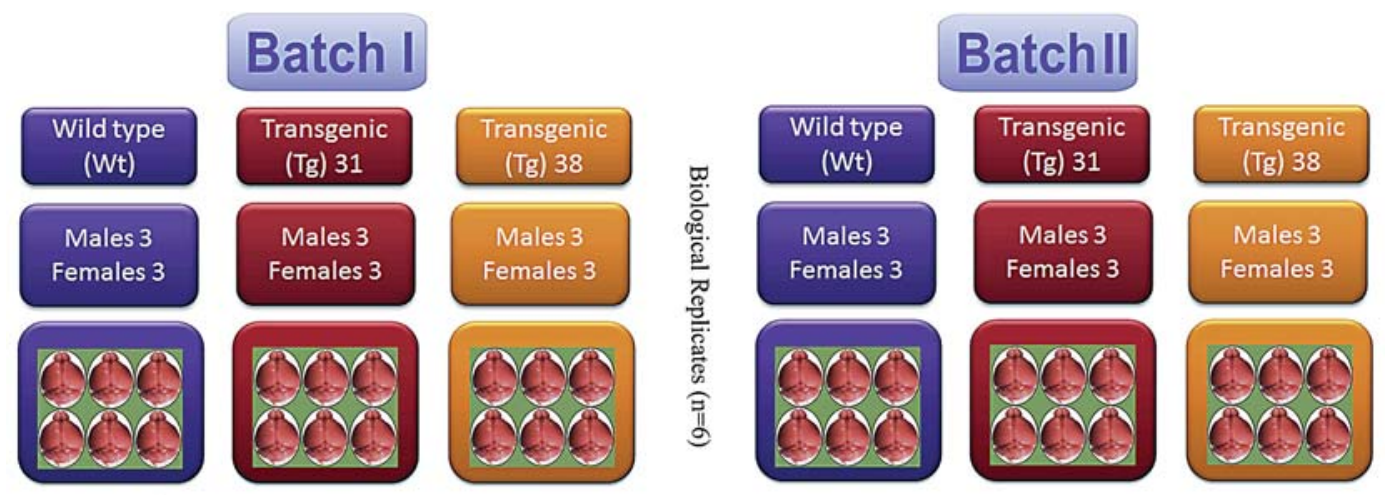

Cortex and Hippocampus were dissected and tissues were lysed

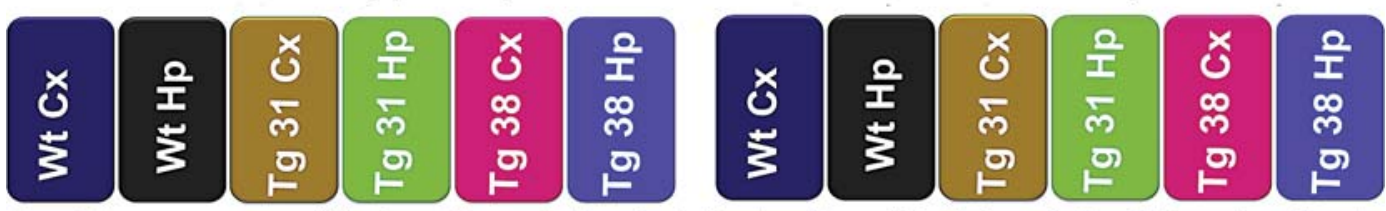

Proteins were quantified and In-gel digested (Reduction, Alkylation \& Peptide extraction)
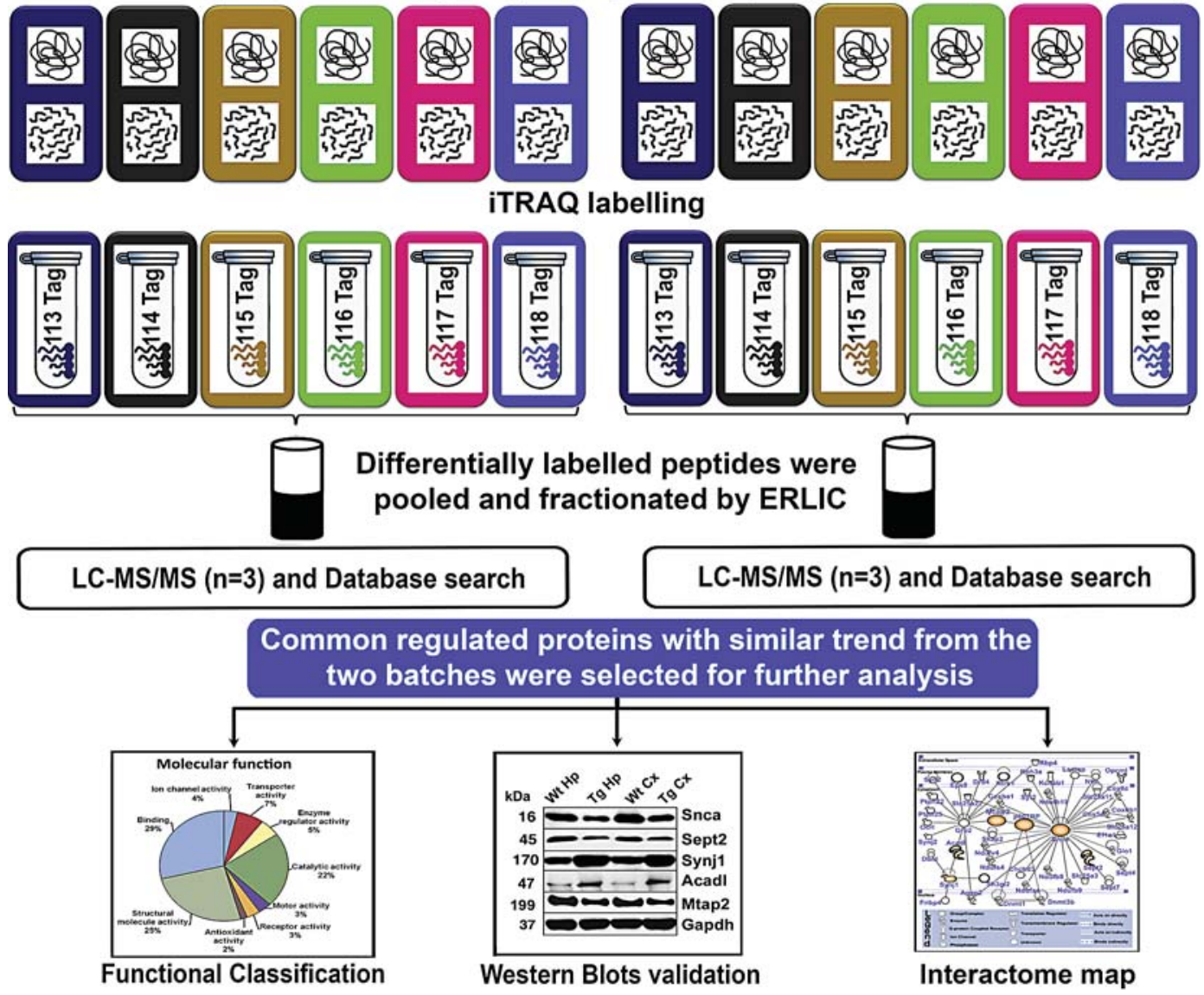
a mortar and pestle. Upon the addition of lysis buffer [2\% SDS, 0.5 $\mathrm{M}$ triethyl ammonium bicarbonate buffer, 1 Complete ${ }^{\mathrm{TM}}$ protease inhibitor cocktail tablet (Roche, Mannheim, Germany) and 1 PhosSTOP phosphatase inhibitor cocktail tablet (Roche)], the samples were vortexed for $1 \mathrm{~min}$ and incubated on ice for an additional $45 \mathrm{~min}$ prior to homogenization (sonication parameters: amplitude, 23\%; pulse: $5 \mathrm{~s} / 5 \mathrm{~s}$ for $5 \mathrm{~min}$ ) using a Vibra Cell highintensity ultrasonic processor (Jencons Scientific Ltd., Leighton Buzzard, UK). After centrifugation $\left(20,000 \mathrm{~g} / 4^{\circ} \mathrm{C} / 30 \mathrm{~min}\right)$, the supernatant was collected and stored at $-80^{\circ} \mathrm{C}$ until further use. The protein concentration was quantified by a '2-D Quant' kit (Amersham, Piscataway, N.J., USA) according to the manufacturer's protocol.

\section{iTRAQ Protocol}

A detailed description of the 2D-LC-MS/MS iTRAQ procedures $[6,7]$, including postproteomic data verification by SDSPAGE/Western blot analyses $[8,9]$, can be found in the online supplementary document (for all online suppl. material, see www. karger.com/doi/10.1159/000343672) as described previously.

\section{Experimental Design}

Six wild-type mice ( 3 males, 3 females) and 6 transgenic mice (3 males, 3 females, for each mouse strain) were used. For each set (B-I and B-II), we used 6 samples to perform iTRAQ (6 wild-type Cxs and Hps and 6 transgenic Cxs and Hps from both mouse strains, respectively, i.e. $\operatorname{tg} 31-\mathrm{Cx}, \operatorname{tg} 31-\mathrm{Hp}, \operatorname{tg} 38-\mathrm{Cx}, \operatorname{tg} 38-\mathrm{Hp})$ as 6 pooled biological replicates. All experiments were performed twice (B-I and B-II; fig. 1) with each set repeated 6 times (separately for each area, $\mathrm{Cx}$ and $\mathrm{Hp}$, and for each mouse strain, $\operatorname{tg} 38$ and $\operatorname{tg} 31$, respectively). This was to ensure high confidence in the detection of brain-region-specific proteins regulated by neuronal p60TRP expression. The quality of the data set and instrumental reproducibility was then confirmed by comparing and combining 3 technical replicates [6] after the samples had been labelled with $113,114,115,116,117$ and 118 isobaric tags and processed by LCMS/MS.

In order to verify that the protein samples were indeed from the whole brain tissue proteome, the identified proteins were uploaded into JVirGel (http://www.jvirgel.de/), a database that creates a virtual 2D gel picture [10].

We used online databases, e.g. Panther (www.pantherdb.org), UniProt, NCBI, and 'softberry' (http://linuxl.softberry.com/ berry.phtml), to classify the functions of the iTRAQ-identified p60TRP-regulated proteins. STRING (Search Tool for the Retrieval of Interacting Genes, http://string-db.org/; Mus musculus, default mode) analysis was carried out to retrieve information about functional partnerships among proteins that constitute the core of complex cellular phenotypes in the transgenic p60TRP brain. Further biocomputational network analysis of the iTRAQidentified p60TRP-regulated proteins using the Ingenuity Pathways Analysis (IPA, http://www.ingenuity.com) offered us additional valuable clues about the complex interactive link of these proteins in the brain.

\section{Statistical Analysis}

The data obtained in the Western blot analyses in this investigation are illustrated as means $\pm \mathrm{SD}$, and Student's t test was applied. IBM-SPSS (IBM Statistical Products and Service Solutions) for Windows version 19 was used to perform ANOVA followed by
Fisher's protected least significant difference post hoc tests, when warranted. For the iTRAQ analysis, ProteinPilot Software 3.0 was used. To be considered statistically significant, we required a probability value to be at least $<0.05$ (95\% confidence limit, $\mathrm{p}<$ $0.05)[5,8,9]$.

\section{Results}

\section{Identification of p60TRP-Regulated Proteins in Mouse}

Brain $\mathrm{Cx}$ and $\mathrm{HP}$

Through iTRAQ we identified a total of 2,025 proteins (Cx and $\mathrm{Hp}$ ), whereby 1,735 proteins were quantified [with a strict cut-off of unused ProtScore $\geq 2$ as the qualification criteria, which corresponds to a peptide confidence level of $99 \%$ and an applied false discovery rate of $0.33 \%(<1.0 \%)$ ]; out of 1,735 proteins $56(\mathrm{Cx}$ and $\mathrm{Hp})$ showed altered protein expression levels that exhibited common trends for both transgenic mouse lines (fig. 1, tables 1-3, online suppl. tables; the cut-off for up- and downregulation was predefined at 1.2 and 0.83 , respectively).

In particular, 24 proteins were significantly modulated in the $\mathrm{Cx}$ (table 1) and 37 proteins were significantly regulated in the $\mathrm{Hp}$ (table 2 ) suggesting a critical role of p60TRP in Hp compared to $\mathrm{Cx}$ functions. Comparing the altered proteins in these two groups, we could identify 5 proteins that were specifically modulated in the $\mathrm{Hp}$ and the Cx (table 3: Snca, Sept2, Mtap2, Acadl and Synj1), 32 proteins (e.g. Ndufv2, Dlg4, Cdh2, Sept9, Camk2a and Syn2) were specifically regulated only in the Hp but not in the $\mathrm{Cx}$ [table 2: 7 proteins upregulated and 25 proteins downregulated (22\%:78\%)], and 19 other proteins (e.g. Sncb, Arf3, Gria2, Sept6, Rin1, Dmxl2, Ranbp1 and S1c12a5) were specifically regulated in the $\mathrm{Cx}$ but not in the Hp [table 1: 8 proteins upregulated and 11 proteins downregulated (42\%:58\%)]. Remarkably, proteins modulated in both sites (Hp and Cx) showed the same trend in either site: if up- or downregulated in the $\mathrm{Hp}$, then also up- or downregulated in the $\mathrm{Cx}$ (table 3). While those proteins modulated specifically in the Hp were mainly downregulated (22\%:78\%; table 2), proteins modulated specifically in the $\mathrm{Cx}$ were regulated almost in equal measure (42\%:58\%; table 1).

\section{Biocomputational Classification of p60TRP-Regulated Proteins}

During the classification process, our objective was also to identify the proteins' subcellular localization and action (fig. 2-4; tables $1-3$ ). While the 56 regulated 
Table 1. Functional classification of iTRAQ-quantified proteins differentially expressed in the Cx of p60TRP transgenic (tg Cx) mouse brains with reference to the wild-type $\mathrm{Cx}$

\begin{tabular}{|c|c|c|c|c|c|c|c|}
\hline Protein IDs & $\begin{array}{l}\text { Gene } \\
\text { symbols }\end{array}$ & Protein names & Biological process & $\begin{array}{l}\text { Peptides } \\
(>95 \%) \\
\mathrm{n}\end{array}$ & $\begin{array}{l}\operatorname{tg} \mathrm{Cx} / \\
\text { wt } \mathrm{Cx}\end{array}$ & $\begin{array}{l}\mathrm{p} \\
\text { value }\end{array}$ & $\begin{array}{l}\text { Subcellular } \\
\text { location }\end{array}$ \\
\hline $\begin{array}{l}\text { Parkinson's disease } \\
\text { IPI00131614.1 }\end{array}$ & Sncb & $\beta$-Synuclein & Neurotransmitter secretion & 5 & 0.57 & 0.03 & Cytoplasmic \\
\hline $\begin{array}{l}\text { Huntington's diseas } \\
\text { IPI00221614.3 }\end{array}$ & Arf3 & ADP-ribosylation factor 3 & Intracellular protein transport & 21 & 0.76 & 0.03 & Golgi \\
\hline $\begin{array}{l}\text { Receptor activity } \\
\text { IPI00608015.1 }\end{array}$ & Gria2 & Glutamate receptor 2 & Neurological system process & 7 & 1.25 & 0.04 & Plasma membrane \\
\hline $\begin{array}{l}\text { Chaperonic response } \\
\text { IPI00230707.6 }\end{array}$ & Ywhag & 14-3-3 protein $\gamma$ & Signal transduction & 39 & 0.76 & 0.04 & Cytoplasmic \\
\hline $\begin{array}{l}\text { GTPase activity/Gp } \\
\text { IPI00473707.3 } \\
\text { IPI00853932.1 } \\
\text { IPI00321978.3 } \\
\text { IPI00122131.1 }\end{array}$ & $\begin{array}{l}\text { rotein } \\
\text { Sept6 } \\
\text { Dmxl2 } \\
\text { Ranbp1 } \\
\text { Rin1 }\end{array}$ & $\begin{array}{l}\text { Septin } 6 \\
\text { DmX-like protein } 2 \\
\text { Ran-specific GTPase-activating } \\
\text { protein } \\
\text { Ras and Rab interactor } 1\end{array}$ & $\begin{array}{l}\text { GTP binding } \\
\text { Intracellular protein transport } \\
\text { Intracellular protein transport } \\
\text { Intracellular protein transport }\end{array}$ & $\begin{array}{l}9 \\
6 \\
4\end{array}$ & $\begin{array}{l}1.49 \\
1.25 \\
0.82\end{array}$ & $\begin{array}{l}0.02 \\
0.03 \\
0.04\end{array}$ & $\begin{array}{l}\text { Cytoplasmic } \\
\text { Cytoplasmic } \\
\text { Cytoplasmic } \\
\text { Cytoplasmic }\end{array}$ \\
\hline $\begin{array}{l}\text { Phosphatases } \\
\text { IPI00120374.1 }\end{array}$ & Ppp2ca & $\begin{array}{l}\text { Serine/threonine protein phosphatase } \\
2 \mathrm{~A} \text { catalytic subunit } \alpha \text { isoform }\end{array}$ & Immune system process & 9 & 1.56 & 0.05 & Cytoplasmic \\
\hline $\begin{array}{l}\text { Microtubule-associa } \\
\text { IPI00311175.5 } \\
\text { IPI00230751.2 } \\
\text { IPI00649104.1 } \\
\text { IPI00128973.1 } \\
\text { IPI00115833.2 } \\
\text { IPI00129519.3 } \\
\text { IPI00153990.1 }\end{array}$ & $\begin{array}{l}\text { ted protei } \\
\text { Tuba8 } \\
\text { Ctnna2 } \\
\text { Mapt } \\
\text { Gap43 } \\
\text { Mtap6 } \\
\text { Basp1 } \\
\text { Actr1b }\end{array}$ & $\begin{array}{l}n / \text { cytoskeletal protein } \\
\text { Tubulin } \alpha_{8} \text { chain } \\
\text { Catenin } \alpha_{2} \\
\text { Microtubule-associated protein } \tau \\
\text { Neuromodulin } \\
\text { Microtubule-associated protein } 6 \\
\text { Brain acid soluble protein } 1 \\
\beta \text {-Centractin }\end{array}$ & $\begin{array}{l}\text { Intracellular protein transport } \\
\text { Cellular component morphogenesis } \\
\text { Apoptosis } \\
\text { Axon choice point recognition } \\
\text { Microtubule binding } \\
\text { Neurological system process } \\
\text { Intracellular protein transport }\end{array}$ & $\begin{array}{r}114 \\
11 \\
12 \\
20 \\
25 \\
22 \\
9\end{array}$ & $\begin{array}{l}1.29 \\
1.37 \\
0.71 \\
0.69 \\
0.49 \\
0.56 \\
0.68\end{array}$ & $\begin{array}{l}0.01 \\
0.01 \\
0.01 \\
0.04 \\
0.01 \\
0.01 \\
0.01\end{array}$ & $\begin{array}{l}\text { Cytoplasmic } \\
\text { Cytoplasmic } \\
\text { Nuclear } \\
\text { Membrane } \\
\text { Cytoplasmic } \\
\text { Cytoplasmic } \\
\text { Cytoplasmic }\end{array}$ \\
\hline $\begin{array}{l}\text { Transport protein } \\
\text { IPI00877254.1 }\end{array}$ & Slc12a5 & Solute carrier family 12 member 5 & Synaptic vesicle/cation transport & 10 & 1.23 & 0.01 & Plasma membrane \\
\hline $\begin{array}{l}\text { Other proteins } \\
\text { IPI00874565.1 } \\
\text { IPI00471441.1 }\end{array}$ & $\begin{array}{l}\text { Nckap1 } \\
\text { Ptms }\end{array}$ & $\begin{array}{l}\text { NCK-associated protein } 1 \\
\text { Parathymosin }\end{array}$ & $\begin{array}{l}\text { Protein stabilization } \\
\text { Nucleotide and nucleic acid } \\
\text { metabolic process }\end{array}$ & $\begin{array}{l}8 \\
6\end{array}$ & $\begin{array}{l}1.24 \\
0.47\end{array}$ & $\begin{array}{l}0.05 \\
0.02\end{array}$ & $\begin{array}{l}\text { Plasma membrane } \\
\text { Nuclear }\end{array}$ \\
\hline
\end{tabular}

The list contains quantitative information of the proteins from transgenic p60TRP mouse Cx compared with wild-type mice. These proteins have met the criteria [i.e. unused ProtScore $>2.0$, false discovery rate of $0.33 \%(<1.0 \%)$, change in expression levels of at least 1.2 -fold (upregulation) or at least $<0.833$-fold (downregulation)] as defined in the experimental procedures. Peptides $=$ The total number of peptides identified with $>95 \%$ confidence; $\mathrm{wt}=$ wild-type mice; $\mathrm{tg}=$ transgenic $60 \mathrm{TRP}$ mice; NCK = non-catalytic region of tyrosine kinase.

proteins had a reasonable distribution in terms of biological process, molecular function and protein class (fig. 2), it is of interest to note that a substantial portion of the identified proteins that were specifically affected in the $\mathrm{Hp}$ were oxidoreductases (approx. 24\%, fig. 3c), while none of the oxidoreductase subgroup proteins were altered in the $\mathrm{Cx}$ and, instead, the number of cytoskeletal proteins were enlarged in the $\mathrm{Cx}$ - hinting at enhanced synaptic plasticity (approx. 26\%, fig. 2c). Interestingly, only in the Hp were p60TRP-regulated pro- teins linked with the plasma membrane. Our proteomic data from $A D$ brain-region-specific studies of human samples also revealed significant alterations in extracellular and plasma membrane-associated proteins in the Hp [unpubl. data]. This implicates that a tight regulation of plasma membrane-associated proteins is a prerequisite for normal functioning of the $\mathrm{Hp}$.

We also realized that some of the p60TRP-regulated proteins could be partially linked with various neurodegenerative diseases such as Parkinson's (PD) or Hunting- 
Table 2. Functional classification of iTRAQ-quantified proteins differentially expressed in the Hp of p60TRP transgenic (tg Hp) mouse brains with reference to the wild-type Hp

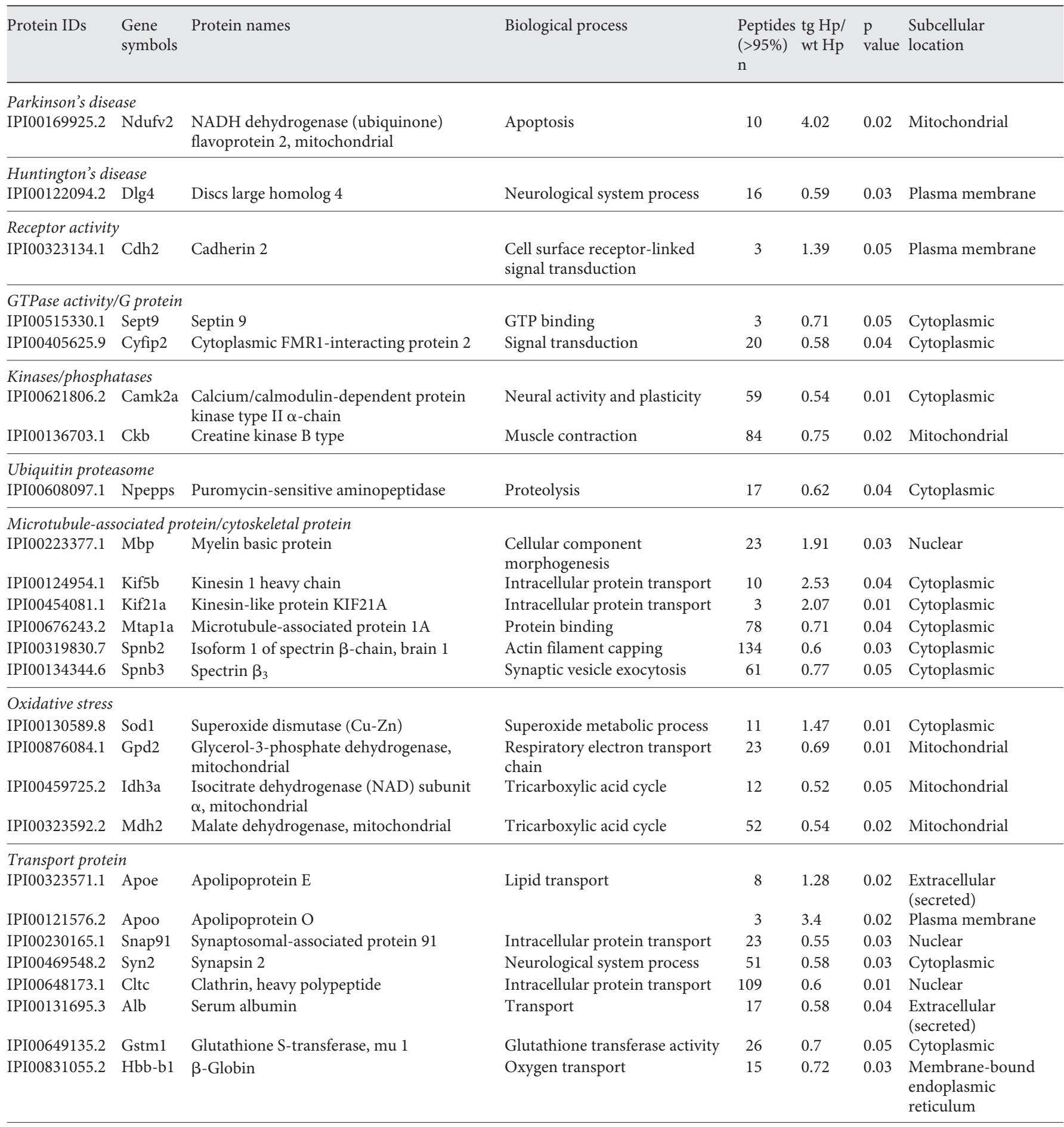


Table 2 (continued)

\begin{tabular}{|c|c|c|c|c|c|c|c|}
\hline Protein IDs & $\begin{array}{l}\text { Gene } \\
\text { symbols }\end{array}$ & Protein names & Biological process & $\begin{array}{l}\text { Peptides } \\
(>95 \%) \\
\mathrm{n}\end{array}$ & $\begin{array}{l}\operatorname{tg} \mathrm{Hp} / \\
\text { wt Hp }\end{array}$ & $\begin{array}{l}\mathrm{p} \\
\text { value }\end{array}$ & $\begin{array}{l}\text { Subcellular } \\
\text { location }\end{array}$ \\
\hline IPI00308882.4 & Ndufs 1 & $\begin{array}{l}\text { NADH ubiquinone oxidoreductase } \\
75-\mathrm{kDa} \text { subunit, mitochondrial }\end{array}$ & $\begin{array}{l}\text { Respiratory electron transport } \\
\text { chain }\end{array}$ & 28 & 0.63 & 0.01 & Mitochondrial \\
\hline IPI00122547.1 & Vdac2 & $\begin{array}{l}\text { Voltage-dependent anion-selective } \\
\text { channel protein } 2\end{array}$ & Anion transport & 16 & 0.73 & 0.05 & Mitochondrial \\
\hline IPI00308162.3 & Slc25a12 & $\begin{array}{l}\text { Calcium-binding mitochondrial carrier } \\
\text { protein Aralar1 }\end{array}$ & Cation transport & 42 & 0.76 & 0.01 & $\begin{array}{l}\text { Membrane-bound } \\
\text { mitochondrial }\end{array}$ \\
\hline \multicolumn{8}{|l|}{ Other proteins } \\
\hline IPI00462072.3 & Eno1 & $\alpha$-Enolase & Glycolysis & 118 & 0.61 & 0.02 & Cytoplasmic \\
\hline IPI00877205.1 & Got1 & $\begin{array}{l}\text { Glutamate oxaloacetate transaminase } 1 \text {, } \\
\text { soluble }\end{array}$ & Aspartate biosynthetic process & 39 & 0.5 & 0.01 & Cytoplasmic \\
\hline
\end{tabular}

The list contains quantitative information of the proteins from transgenic p60TRP mouse Hp compared with wild-type mice. These proteins have met the criteria [i.e. unused ProtScore $>2.0$, false discovery rate of $0.33 \%(<1.0 \%)$, change in expression levels of at least 1.2 -fold (upregulation) or at least $<0.833$-fold (downregulation)] as defined in the experimental procedures. Peptides $=$ The total number of peptides identified with $>95 \%$ confidence; $\mathrm{wt}=$ wild-type mice; $\operatorname{tg}=$ transgenic p60TRP mice.

Table 3. Functional classification of iTRAQ-quantified proteins differentially expressed in the Cx and Hp of p60TRP transgenic mice with reference to the wild-type $\mathrm{Cx}$ and $\mathrm{Hp}$

\begin{tabular}{|c|c|c|c|c|c|c|c|c|c|}
\hline Protein IDs & $\begin{array}{l}\text { Gene } \\
\text { symbols }\end{array}$ & Protein names & Biological process & $\begin{array}{l}\text { Peptides } \\
(>95 \%) \\
\mathrm{n}\end{array}$ & $\begin{array}{l}\operatorname{tg} \mathrm{Cx} / \\
\text { wt } \mathrm{Cx}\end{array}$ & $\begin{array}{l}\mathrm{p} \\
\text { value }\end{array}$ & $\begin{array}{l}\operatorname{tg} \mathrm{Hp} / \\
\text { wt Hp }\end{array}$ & $\begin{array}{l}\mathrm{p} \\
\text { value }\end{array}$ & $\begin{array}{l}\text { Subcellular } \\
\text { location }\end{array}$ \\
\hline $\begin{array}{l}\text { Parkinson's dise } \\
\text { IPI00845803.1 }\end{array}$ & $\begin{array}{l}\text { ase } \\
\text { Snca }\end{array}$ & $\alpha$-Synuclein & Fatty acid metabolic process & 4 & 0.79 & 0.05 & 0.78 & 0.03 & Cytoplasmic \\
\hline $\begin{array}{l}\text { GTPase activity } \\
\text { IPI00114945.1 }\end{array}$ & $\begin{array}{l}\text { Gprotein } \\
\text { Sept2 }\end{array}$ & Septin 2 & GTP binding & 5 & 0.8 & 0.05 & 0.71 & 0.04 & Cytoplasmic \\
\hline $\begin{array}{l}\text { Phosphatases } \\
\text { IPI00850983.1 }\end{array}$ & Synj1 & Synaptojanin 1 & $\begin{array}{l}\text { Inositol phosphate } \\
\text { dephosphorylation }\end{array}$ & 5 & 2.75 & 0.05 & 2.88 & 0.05 & Cytoplasmic \\
\hline $\begin{array}{l}\text { Mitochondrial f } \\
\text { IPI00894588.1 }\end{array}$ & $\begin{array}{r}\text { roteins } \\
\text { Acadl }\end{array}$ & $\begin{array}{l}\text { Long-chain acyl-CoA } \\
\text { dehydrogenase }\end{array}$ & Fatty acid metabolism & 3 & 1.31 & 0.05 & 1.41 & 0.05 & $\begin{array}{l}\text { Membrane-bound } \\
\text { mitochondrial }\end{array}$ \\
\hline $\begin{array}{l}\text { Microtubule-as } \\
\text { IPI00895965.1 }\end{array}$ & $\begin{array}{l}\text { ociated pr } \\
\text { Mtap2 }\end{array}$ & $\begin{array}{l}\text { tein/cytoskeletal protein } \\
\text { Microtubule-associated } \\
\text { protein } 2\end{array}$ & Dendrite development & 58 & 0.74 & 0.001 & 0.7 & 0.001 & Cytoplasmic \\
\hline
\end{tabular}

The list contains quantitative information of the proteins from transgenic p60TRP mouse Hp and Cx compared with-wild type mice. These proteins have met the criteria [i.e. unused ProtScore $>2.0$, false discovery rate of $0.33 \%(<1.0 \%)$, change in expression levels of at least 1.2 -fold (upregulation) or at least $<0.833$-fold (downregulation)] as defined in the experimental procedures. Peptides $=$ The total number of peptides identified with $>95 \%$ confidence; $\mathrm{wt}=$ wild-type mice; $\mathrm{tg}=$ transgenic p60TRP mice. 


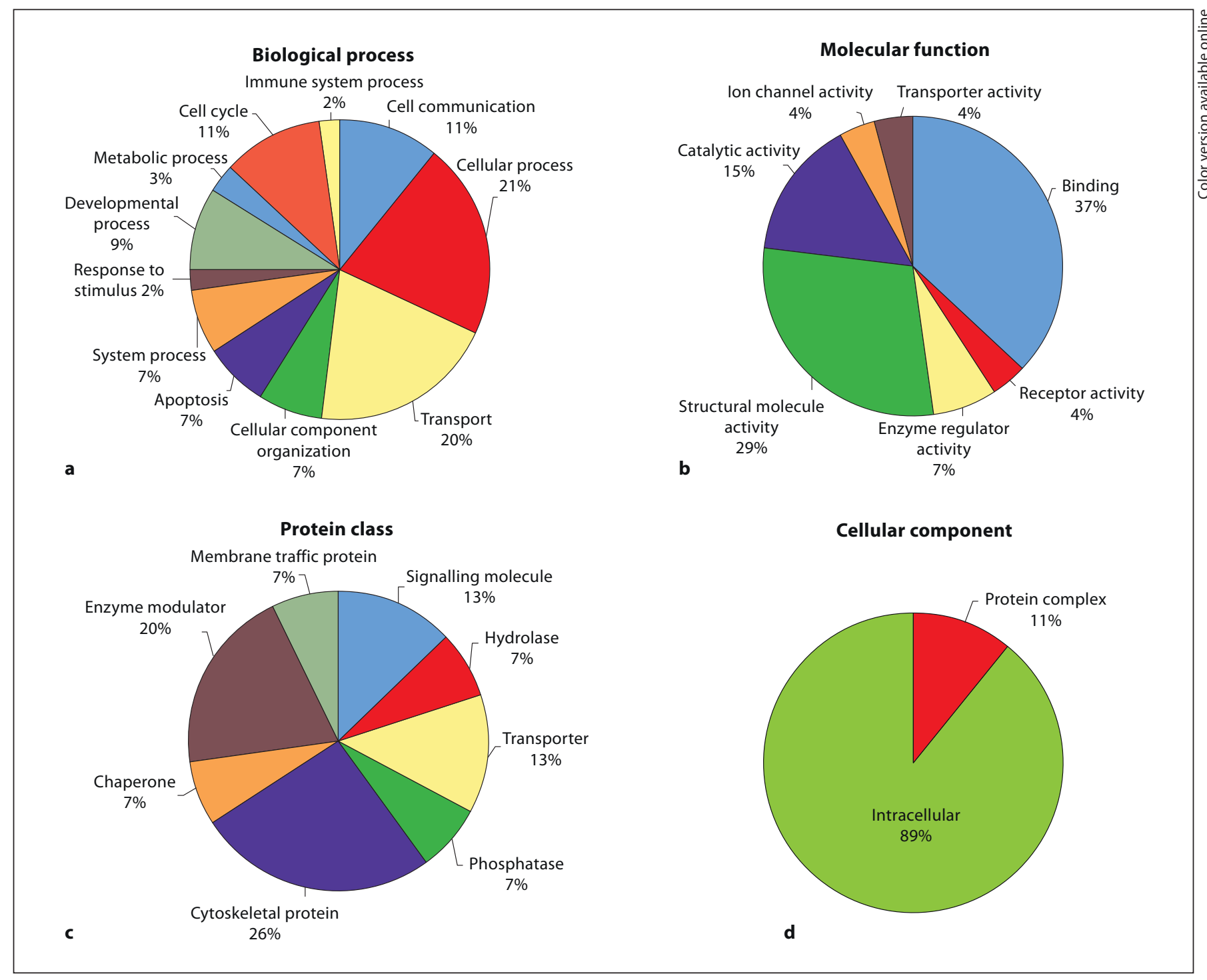

Fig. 2. Pie chart depicting the classification of p60TRP-regulated proteins in the Cx characterized by iTRAQ within the molecular function gene ontology category. Subcellular and functional categories were based on the annotations of gene ontology using the mouse genome informatics (MGI) GO_Slim Chart Tool. Analyses were done based on the following categories: biological process (a); molecular function (b); protein class (c), and cellular component (subcellular compartment, d). ton's diseases (e.g. Snca/b, Ndufv2, Dlg4 and Arf3; tables 1-3), familial amyotrophic lateral sclerosis, schizophrenia and depressive disorder, suggesting a convergent nature of neurodegenerative mechanisms, hence linking different types of neurodegenerative disorders.

\section{Data Validation by Western Blot}

Following the database search and classification of proteins, Western blots were performed on randomly selected proteins to verify the iTRAQ values. Ten proteins, (Snca,
Sept2, Synj1, Acadl, Mtap2, Mbp, Sod1, Sncb, Tuba8 and Gapdh) were used for validation (fig. 5). Gapdh was used as an internal control to ensure equal loading of the samples as its level was also unchanged in the iTRAQ analyses.

Remarkably, the Western blot images correlated very well and thus confirmed the iTRAQ values obtained.

\section{Biocomputational Network Analyses}

The networks formed by the interacting proteins provided us crucial scaffolds for modelling the brain 

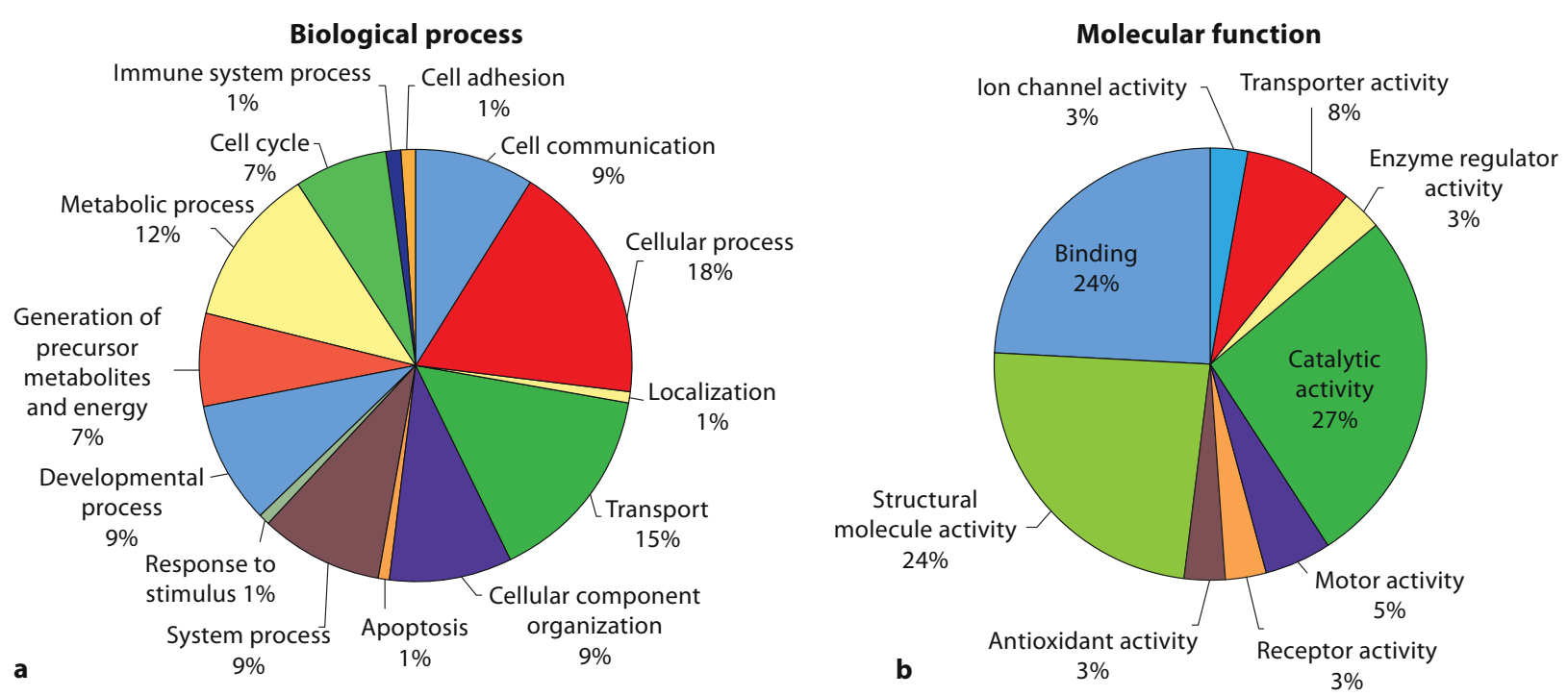

Fig. 3. Pie chart depicting the classification of p60TRP-regulated proteins in the Hp characterized by iTRAQ within the molecular function gene ontology category. Subcellular and functional categories were based on the annotations of gene ontology using the mouse genome informatics (MGI) GO_Slim Chart Tool. Analyses were done based on the following categories: biological process (a); molecular function (b); protein class (c), and cellular component (subcellular compartment, d). system level mechanisms of cellular events involved in p60TRP-mediated brain functions. It revealed the functional link among metabolically modulated proteins specifically regulated in the $\mathrm{Cx}$ and $\mathrm{Hp}$, respectively (fig. 6, 7). In particular, it shows the link between p60TRP and Cdk proteins - a possible pathway through which p60TRP can modulate synaptic plasticity $[4,11]$, eventually via influencing the anaphase-promoting complex as shown previously by others $[5,12]-$, and the link between p60TRP and Ipo5, thus implicating a potential role of p60TRP within the nucleus. Besides, p60TRP's influence on oxidoreductases (Nduf, Sod1) and heat shock proteins (Hspd1 and Hspe1) may make the vulnerable Hp more stable against oxidative stress (fig. 7). Moreover, the physical interaction of p60TRP with Pp2ca connects it with several essential and life- 


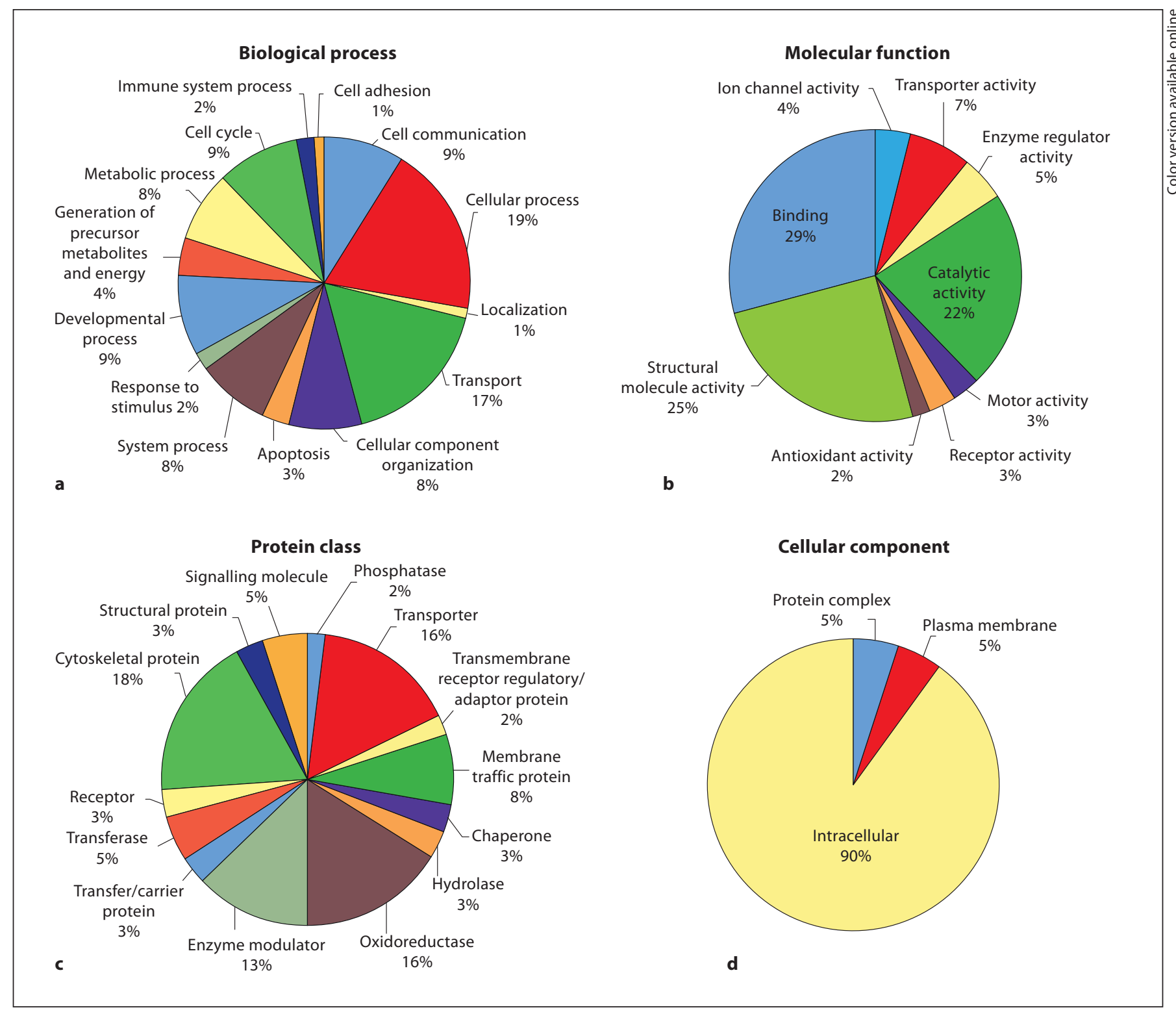

Fig. 4. Pie chart depicting the classification of p60TRP-regulated proteins in the $\mathrm{Hp}$ and $\mathrm{Cx}$ characterized by iTRAQ within the molecular function gene ontology category. Subcellular and functional categories were based on the annotations of gene ontology using the mouse genome informatics (MGI) GO_Slim Chart Tool. Analyses were done based on the following categories: biological process (a); molecular function (b); protein class (c), and cellular component (subcellular compartment, d). sustainable metabolic processes such as survival, synaptogenesis and long term potentiation.

Considering p60TRP's influence on AD-related signalling [4], IPA could demonstrate p60TRP's impact on cortical and hippocampal proteins and the affected network with synaptic plasticity-relevant proteins such as Ntm, Ntrk1, Lsamp, Mtap2, Snca, Synj1/2, Syn2 and others (fig. 8).

\section{Discussion}

GPCRs are considered as the largest superfamily of membrane proteins that translate extracellular signals into intracellular messages and serve as one of the best targets for diverse therapeutic applications. p60TRP has recently been found as novel member of the GPRASP family [3] and the in vivo relevance of p60TRP-dependent 
Fig. 5. Western blot validation of iTRAQ results by randomly selected proteins significantly regulated in transgenic p60TRP mouse-derived brains (common trends in both transgenic p60TRP mouse strains $\operatorname{tg} 38$ and tg31) compared with controls. a Western blots using proteins that showed similar trends in the Hp and Cx. Synj1 and Acadl levels increased while Snca, Sept2 and Mtap2 levels were reduced in p60TRP transgenic mice. b Western blots using proteins that showed significant changes either in the Hp (upper panel: Mbp and Sod1 with increased protein expression levels) or Cx (lower panel: Sncb decreased while Tuba8 increased). In $\mathbf{a}$ and $\mathbf{b}$, Gapdh was used as internal control and it was unchanged in the iTRAQ analysis as well. c Quantitative analyses of the Western blots shown in $\mathbf{a}$ and $\mathbf{b}$. Western blot experiments were performed at least 3 times for statistical quantification and analyses $(\mathrm{n}=3)$. Values (= relative protein expression) represent the ratio of densitometric scores for the respective Western blot data, and statistical error was indicated as mean $\pm \mathrm{SD}\left({ }^{*} \mathrm{p}<0.05\right)$ using the Gapdh bands as reference. The Western blots correlated with the iTRAQ values obtained. d The histogram indicates similar ratios of the iTRAQ expression levels (tg p60TRP Hp vs. wt Hp and tg p60TRP Cx vs. wt Cx if compared with the Western blot ratios for selected proteins (c).
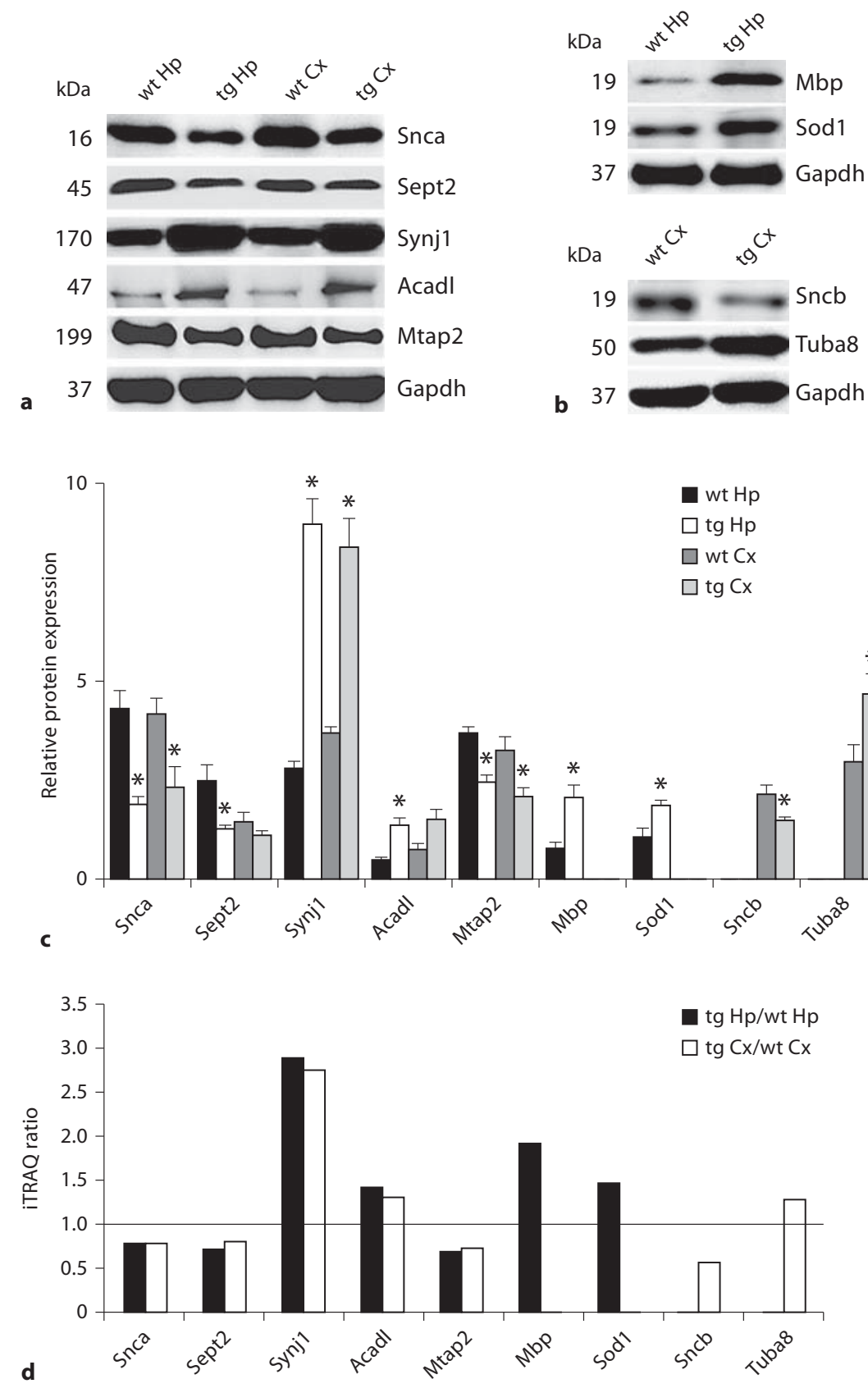

signalling has also begun to be verified in a mouse model overexpressing neuronal p60TRP [4]. Further considering p60TRP's neuroprotective effects in $\mathrm{AD}$, one could predict its feasibility in the treatment of $\mathrm{AD}$ as well as other neurodegenerative disorders. Hence, here we investigated in vivo the long-term effect of neuronal p60TRP overexpression on the brain-region-specific proteome metabolism. Successively, 56 proteins with altered expression were identified in the $\mathrm{Hp}$ and $\mathrm{Cx}$ of transgenic p60TRP mice.

In the following sections, the specific functional roles of several of these iTRAQ-identified proteins, their rele- 


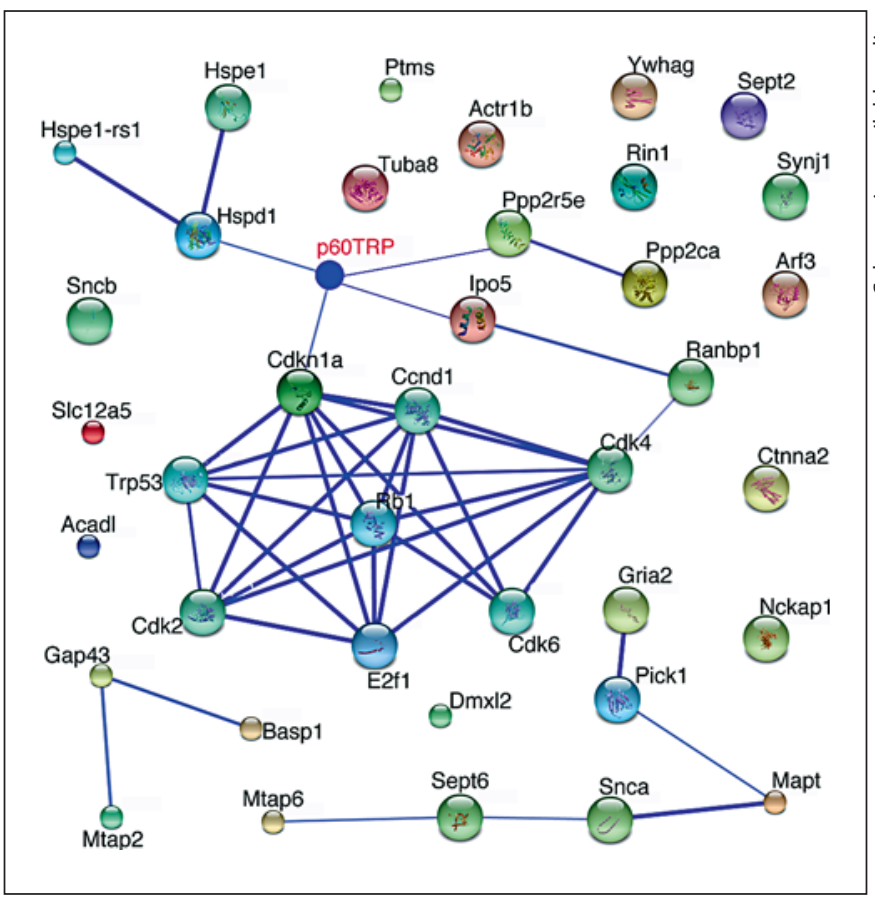

Fig. 6. STRING-9.0 analysis of transgenic p60TRP-modulated proteins in the brain cortex: Different coloured lines represent the types of evidence for the association. Network display: Nodes are either coloured (if they are directly linked to the input as in the tables 1 and 3) or white (nodes of a higher iteration/depth). Edges, i.e. predicted functional links, consist of up to eight lines: one colour for each type of evidence. vance to brain diseases and the potential consequences of their p60TRP-mediated modified expressions are discussed.

Neuronal p60TRP Expression Specifically Mediates the Regulation of Cortical Proteins Crucially Involved in Brain Functions

\section{Gria2 Protein}

The Gria2 gene product (also known as GluA2, GluR$\mathrm{K} 2$, GluR2 or GluR-B) belongs to a family of ionotropic glutamate receptors (GluRs) that are sensitive to $\alpha$-amino-3-hydroxy-5-methyl-4-isoxazole propionate (AMPA), and function as ligand-activated cation channels. Regulation of AMPA receptors (AMPARs) has emerged as a key mechanism of long-term potentiation and long-term depression during processes related to synaptic plasticity $[13,14]$. Analysis from post-mortem brains revealed a particularly prominent reduction of AMPAR subunit Gria1 and Gria 2 expression in the prefrontal $\mathrm{Cx}$ of patients with schizophrenia. This finding supports and expands the hypothesis of glutamatergic dysfunction in the $\mathrm{Cx}$ during pathophysiological processes of schizophrenia [15]. Taken together, p60TRP may enhance synaptic plasticity through its positive impact on Gria2. Thus, interference with the cross-talk between p60TRP-GPCR and AMPAR signalling pathways may eventually become of interest for the treatment of diseases such as schizophrenia.
Fig. 7. STRING-9.0 analysis of transgenic p60TRP-modulated proteins in the brain hippocampus: differently coloured lines (colours seen in the online version only) represent the types of evidence for the association. Network display: nodes are either coloured (if they are directly linked to the input as in tables 2 and 3) or white (nodes of a higher iteration/depth). Edges, i.e. predicted functional links, consist of up to 8 lines, with 1 colour for each type of evidence.

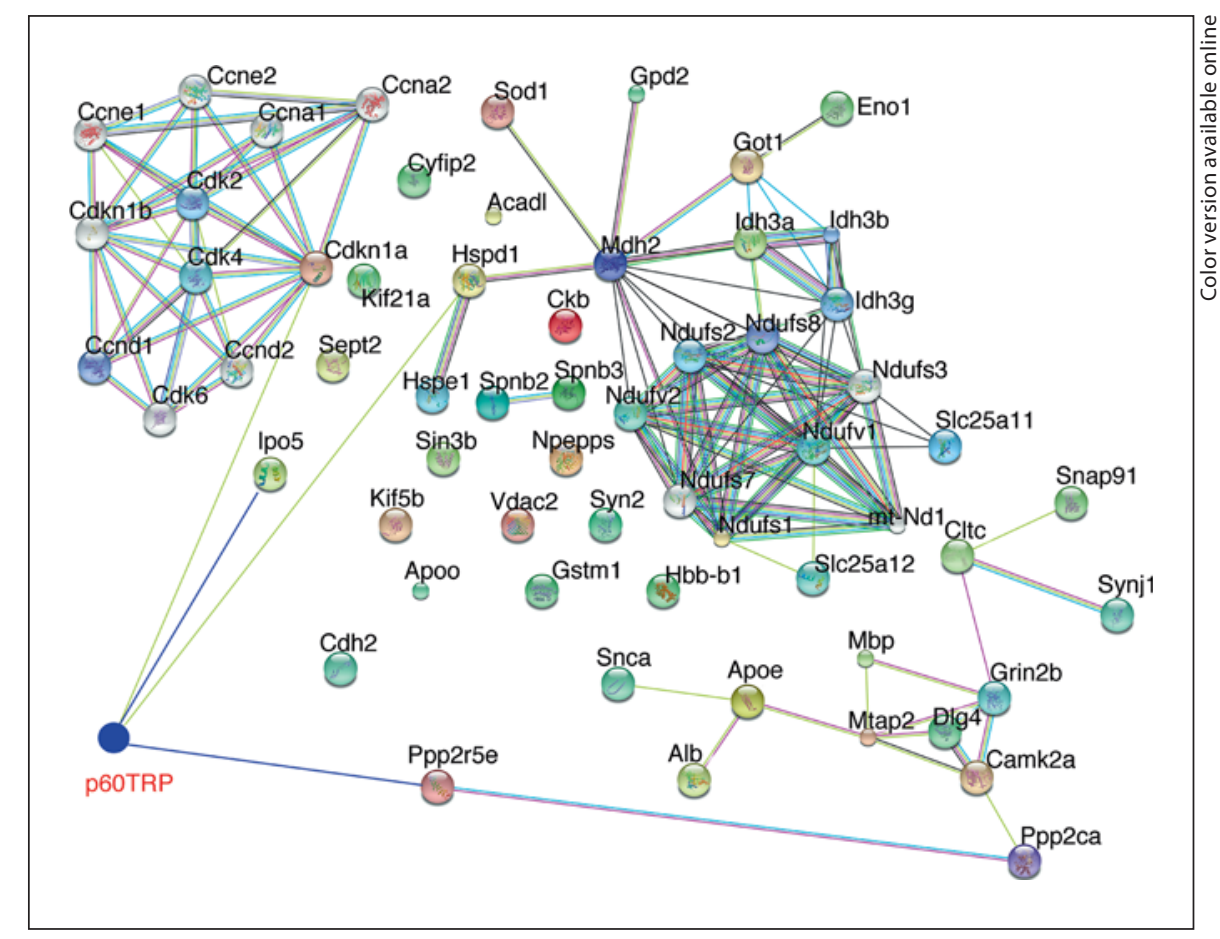




\section{Rin1 Protein}

Rin proteins serve as guanine nucleotide exchange factors for Rab5 GTPases. Rin1 is the prototype of this new family that has been shown to play an important role in the endocytosis of various receptors including the epidermal growth factor receptor [16-19]. Rin1 is preferentially expressed in postnatal forebrain neurons in which it is localized in dendrites and physically associated with Ras, suggesting a role in Raf-Mek-Erk-pathway-mediated postsynaptic neuronal plasticity. It has been shown that Rin1 modulates neuronal plasticity in forebrain neurons where it blocks fear conditioning and amygdala longterm potentiation to inhibit the acquisition of fear memories [20-22]. The results indicate that Rin1 serves as an inhibitory modulator of neuronal plasticity in aversive memory formation [23]. An underlying mechanism of Rin1 function in amygdala is to downregulate EphA4 sig- nalling by promoting its endocytosis [24]. Accordingly, p60TRP may strengthen synaptic plasticity through the downregulation of Rin1. Moreover, p60TRP mice revealed higher tendency to explore their surroundings and reduced Rin1 activity would serve as a tool to provoke acquisition of fear conditioning; hence, p60TRP mice are more clever compared to their wild type littermates.

\section{Dmxl2 Protein}

Dmxl2 binds both GDP/GTP exchange protein and GTPase-activating protein for the Rab3 small $G$ protein family that regulates $\mathrm{Ca}^{2+}$-dependent exocytosis of neurotransmitters [25,26], Dmxl2 is also a functional regulator of mammalian Notch signalling [27], and thereby modulating neurogenesis $[28,29]$. Its upregulation by p60TRP may cause enhanced neuronal synaptic activities resulting in increased synaptic plasticity.
Fig. 8. Interactome maps demonstrating direct and indirect relationships among the iTRAQ-identified proteins with altered expression in the $\mathrm{Cx}$ and $\mathrm{Hp}$ of p60TRP transgenic mice. IPA was done to reveal the network of p60TRP-regulated proteins. The interactome shows that the 5 proteins identified by our iTRAQ analysis (Acadl, Mtap2, Sept2, Snca and Synj1) regulate either directly or indirectly the activities of several biomarkers and proteins involved in neurological diseases.

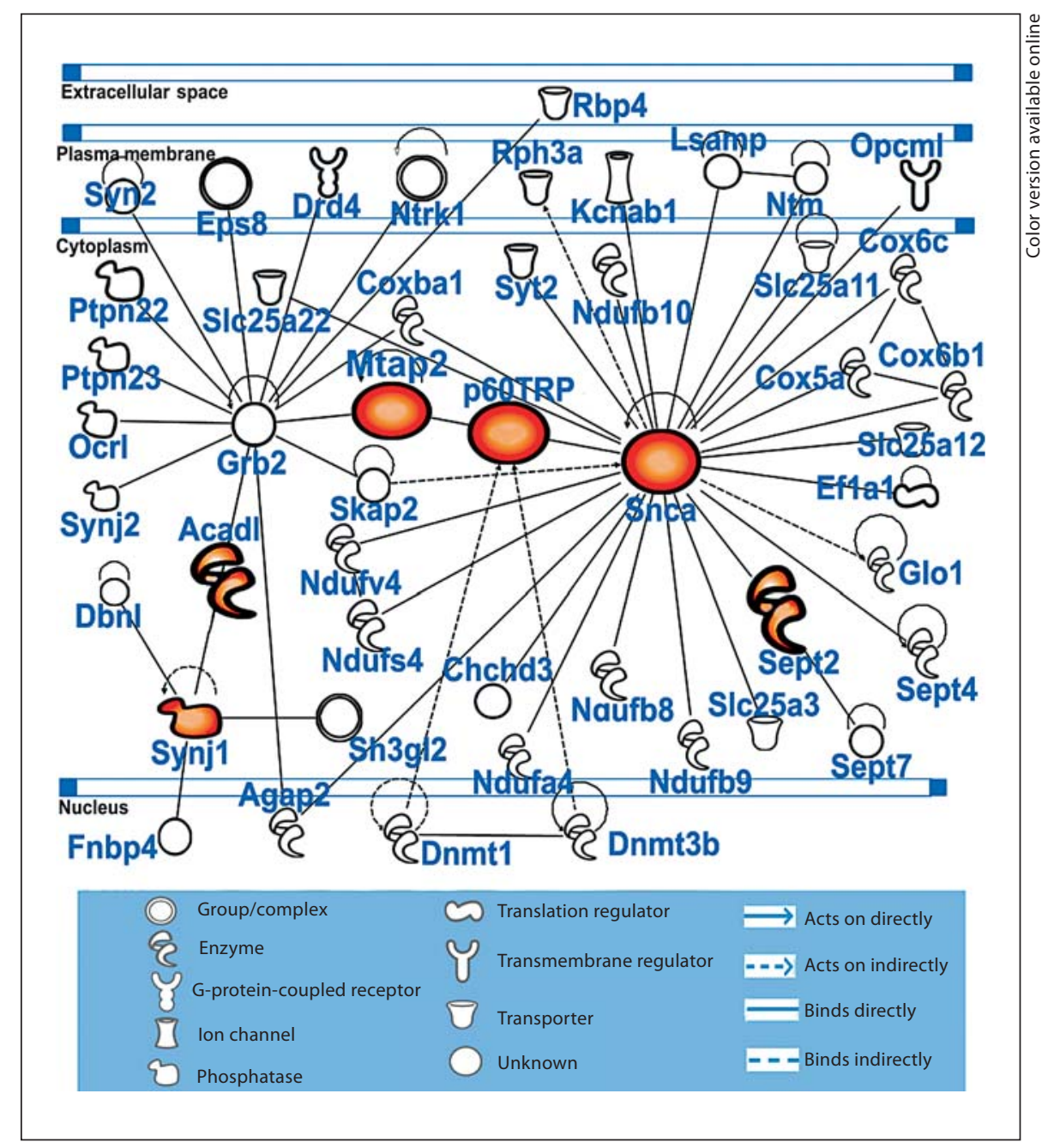




\section{Basp1 Protein}

Similar to Gap43, the brain abundant membrane-attached signal protein 1 (Basp1) is intensively present in nerve endings [30], and increased expression has been associated with the neuritic and synaptic dysfunction and pathogenesis of schizophrenia [31]. p60TRP-mediated downregulation of Baspl might be associated with normal synaptic functions mediating neuroprotection.

\section{Sncb Protein}

Among the proteins downregulated in p60TRP transgenic mouse brains was Sncb, a protein involved in neurotransmitter release from nerve terminals and in the integration of signal transduction and membrane vesicle trafficking at nerve terminals. The synucleins $(\alpha, \beta$ and $\gamma)$ are highly homologous proteins thought to play a role in regulating neurotransmission and are found abundantly in presynaptic terminals [32]. Besides, the proteins have the functional ability to induce membrane curvature and to convert large vesicles into highly curved membrane tubules and are thus involved in vesicle trafficking and endocytosis [33]. The Sncb protein is highly homologous to Snca and has been shown to be highly expressed in the substantia nigra of the brain, a region of neuronal degeneration in patients with $\mathrm{PD}$; however, no direct relation to PD has been established; in contrast, Sncb rather inhibits Snca protein aggregation [34-36].

\section{Sept6 Protein}

Septins are an evolutionarily conserved group of GTP-binding and filament-forming proteins that belong to the large superclass of P-loop GTPases. Recent studies reveal that septins associate with microtubules, microtubule-associated proteins and microtubule motors, and are also involved in dendritic spine formation $[37,38]$. Additionally, they are involved in processes controlling neurotransmitter release [39]. Functions identified to date include also cell apoptosis, DNA damage response, vesicle trafficking, cytoskeletal reorganization and membrane dynamics, and alterations of these septin GTPase scaffolds, by mutation or expression changes, have also been associated with a variety of neurological disorders such as AD and PD [40-42]. For Sept 6 it could be demonstrated that it has an increase in expression from embryonic day 15 to postnatal day 70 , and is abundantly expressed in axons and growth cones of developing neurons, found in neuronal vesicles of presynaptic terminals [43]. In addition, it has been shown that the transmembrane myelin protein Mal interacts with the cytoskeleton protein Sept6 for mem- brane compartmentalization in myelin internodes [44]. The significance of its upregulation by p60TRP, however, needs further investigations.

\section{Slc12a5 Protein}

Slc12a5 is an integral membrane $\mathrm{K}^{+}-\mathrm{Cl}^{-}$cotransporter that can function in either a net efflux or influx pathway, depending on the chemical concentration gradients of $\mathrm{K}^{+}$ and $\mathrm{Cl}^{-}$. The encoded protein can act as a homomultimer or as a heteromultimer with other $\mathrm{K}^{+}-\mathrm{Cl}^{-}$cotransporters, to maintain $\mathrm{Cl}^{-}$homeostasis in neurons. Increase expression in Slc12a5 correlates with the previous findings of an increased vesicular glutamate transporter Slc17a7 [4] and is pivotal for the maturation of the CNS GABAergic neurotransmission system $[45,46]$.

\section{4-3-3 Protein $\gamma$}

14-3-3 Protein $\gamma$ (Ywhag) belongs to the 14-3-3 family of proteins which mediate signal transduction by binding to phosphoserine-containing proteins. It has been shown to interact with Raf1 and protein kinase C, proteins involved in various signal transduction pathways. Ywhag interacts with Lrrk2 (leucine-rich repeat protein kinase 2) and Syna to protect dopaminergic neurons from $\alpha$-synuclein toxicity. Ywhag's downregulation is probably associated with the reduced expression of Snca/b $[47,48]$. An upregulation might rather cause oncogenic Mapk and Pi3k signalling activation and cell transformation [49]. Similarly, the p60TRP-induced inhibition of Actrlb could be linked to the regulation of Snca/b [50].

\section{Arf3 Protein}

ADP ribosylation factors are highly conserved approximately $20-\mathrm{kDa}$ guanine nucleotide-binding proteins that play crucial roles in neuronal intracellular vesicular transport and in regulations of phospholipidmodifying enzyme activities and cytoskeletons $[51,52]$. Findings by Suzuki et al. [53] suggest that ADP ribosylation factors are differentially involved in some processes essential to nerve regeneration as well as neuronal differentiation and maturation. Thus, the regulatory influence of p60TRP on Arf3 could have a wider impact on neuronal differentiation (e.g. neuronal stem cells activated and recruited to affected areas upon nerve injury) and neuronal regeneration in the CNS.

Tuba8 Protein

It is conceivable that despite its low expression level in the CNS, Tuba8 serves some unique function that is es- 
sential to the developing brain, and mutations in Tuba8 might be involved in polymicrogyria and optic nerve hypoplasia [54].

\section{Ppp2ca Protein}

Increased expression of Ppp2ca correlates with higher protein phosphatase $2 \mathrm{~A}$ activity in transgenic p60TRP mice and is of interest in view of $\mathrm{AD}$-related signalling [4] though other recent findings report that a genetic variation in the tau protein phosphatase-2A pathway is not associated with $\mathrm{AD}$ risk [55].

\section{Gap43 Protein}

GAP43 promotes axon growth by multiple synergistic mechanisms that potentiate the intrinsic motility of the elongating processes, while reducing their sensitivity to environmental inhibition [56, 57].

\section{Ptms Protein}

Ptms is a ubiquitous small acidic nuclear protein that is thought to be involved in cell cycle progression, proliferation and cell differentiation though is function in the brain is still unknown [58]. Data suggest a role of Ptms in the remodelling of higher-order chromatin structure through modulation of histone $\mathrm{H}_{1}$ interaction with nucleosomes and point to its involvement in chromatin-dependent functions [59].

\section{Neuronal P60TRP Expression Specifically Mediates the Regulation of Hippocampal Proteins Crucially \\ Involved in Brain Functions \\ Ndufv2 Protein}

The NADH-ubiquinone oxidoreductase complex (complex I) of the mitochondrial respiratory chain catalyses the transfer of electrons from NADH to ubiquinone, and consists of at least 43 subunits. The complex is located in the inner mitochondrial membrane. Ndufv2 encodes the $24-\mathrm{kDa}$ subunit of complex I and is involved in electron transfer. Mutations in Ndufv2 are implicated in PD, bipolar disorder and schizophrenia [60-66].

\section{Dlg4 Protein}

Dlg4 (also known as PSD95) is a member of the membrane-associated guanylate kinase family and is recruited into N-methyl-D-aspartate receptor (NMDAR) and potassium channel clusters to regulate the strength of synaptic activity. Dlg4 interacts with several other scaffolding proteins to serve as anchorages also for ionotropic AMPAselective GluRs such as Gria2 [67]. Modifications of Dgl proteins function in the glutamatergic synapse, such as alterations of their interaction with NMDAR regulatory subunits, and are common events in several neurodegenerative disorders [68-71]. Decreased expression of NMDAR-associated proteins has been found in the frontal Cx of elderly patients with schizophrenia [72] while decreased levels of Dlg4 have been reported in the Hp from subjects with amnestic mild cognitive impairment [73] and in the inferior temporal $\mathrm{Cx}$ of $\mathrm{AD}$ subjects [74]; in contrast, a significant increase in Dlg4 protein in Brodmann's area 9 of $\mathrm{AD}$ patients suggests a brain-site-specific change in NMDAR trafficking and may represent a novel marker of functional significance for the disease [75]. TrkB receptor and $\mathrm{PKM} \zeta$, two critical regulators of synaptic plasticity, facilitate Dlg4 targeting to synapses [76]. Thus, p60TRP can influence synaptic plasticity directly via modulation of ionotropic AMPARs (Gria2) and/or indirectly via its modulatory role on Dlg4/NMDAR levels.

\section{Camk2a Protein}

The $\mathrm{Ca}^{2+} /$ calmodulin-dependent serine/threonine protein kinase Camk2a is crucial for several aspects of plasticity at glutamatergic synapses such as hippocampal NMDAR-dependent long-term potentiation and spatial learning [77]. Postsynaptic secretion of brain-derived neurotrophic factor and neurotrophin-3 from hippocampal neurons also depends on Camk2, $\mathrm{Ca}^{2+}$ and protein kinase A signalling [78]. Camk2a deficiency causes an immature dentate gyrus, dysregulated behaviours and impaired neuronal development as observed in psychiatric disorders [79].

Another interesting point is that active proteolysis by the ubiquitin-proteasome pathway system has emerged as a new molecular mechanism that controls synaptic plasticity [80]. Besides, the neuronal ubiquitin-proteasome pathway system is itself rapidly and dynamically regulated by synaptic activity. Blockade of action potentials inhibits the activity of the proteasome, whereas the up-regulation of action potentials increases the activity of the proteasome. Camk2a stimulates proteasome activity and directly phosphorylates Rpt6, a subunit of the 19S (PA700) subcomplex of the 26S proteasome. This is a novel mechanism whereby p60TRP can influence Camk2a activity that may regulate the proteasome in neurons to facilitate remodelling of synaptic connections through protein degradation [81]. Since p60TRP mediates the upregulation of excitatory ionotropic GluR signalling mechanisms via Dlg4 and Gria2, the downregulation of Camk2a might be via a feedback loop to control synaptic plasticity in order to avoid excitatory neurotoxicity [82-85]. 


\section{Sod1 Protein}

Sod1 binds copper and zinc ions and is one of two isozymes responsible for scavenging free superoxide radicals/reactive oxygen species in the cell. Mutant Sod1 has been associated with familial amyotrophic lateral sclerosis $[86,87]$. The upregulation of Sod1 might also be via a feedback loop to control synaptic plasticity in order to avoid excitatory neurotoxicity mediated by oxidative stress and reactive oxygen species due to the enhanced levels of Gria2 and Dlg4 [85, 88].

\section{Sept9 Protein}

Sept 9 can substitute for septins of the Sept 2 group and partially for Sept7 $[42,89]$. Since Sept9 is a member of the cytoskeleton-related septin family, which is highly expressed in glia cells in neuronal tissues, neuronal p60TRP modulates also glia functions. Sept9 is thought to function through interaction with other septins and small GTPase rho-mediated signalling. Sequence alterations in Sept 9 are known to cause hereditary neuralgic amyotrophy. Sequence variations in Sept9 causing hereditary neuralgic amyotrophy are thus likely to alter modes of interaction with partner molecules in cells, and consequently contribute to the pathogenesis of hereditary neuralgic amyotrophy [90-92]. While p60TRP mediated reduced Sept9 expression levels, its overexpression would probably cause malignant brain glia tumors [93].

\section{Neuronal p60TRP Expression Specifically Mediates}

the Regulation of Cortical and Hippocampal Proteins

Crucially Involved in Brain Functions

Synj1 Protein

Endocytosis of the synaptic vesicle is a complicated process, in which many proteins and lipids participate. Phosphatidylinositol 4,5-bisphosphate $\left[\mathrm{PI}(4,5) \mathrm{P}_{2}\right]$ plays important roles in the process, and the dynamic regulation of this lipid is one of the key events. Synj1 is the major constitutively active phosphatidylinositol-3,4,5trisphosphate 5-phosphatase in rodent brain that regulates the levels of membrane $\mathrm{PI}(4,5) \mathrm{P}_{2}$ [94]. Cyclin-dependent kinase 5 phosphorylates Synj1 and inhibits the inositol 5-phosphatase activity of Synj1, whereas dephosphorylation by calcineurin stimulates such activity [95].

Besides, SYNJ1 maps to human chromosome 21 and is thus a candidate for an involvement in the AD-related disease Down's syndrome, a complex disorder resulting from the overexpression of trisomic genes. $\mathrm{PI}(4,5) \mathrm{P}_{2}$ metabolism is altered in the brain of Ts65Dn mice, the most commonly used model of Down's syndrome. This defect is rescued by restoring Synj1 to disomy in these Ts65Dn mice and is recapitulated in transgenic mice overexpressing Synj1. These transgenic mice also exhibit cognitive deficits, suggesting that $\mathrm{PI}(4,5) \mathrm{P}_{2}$ dyshomeostasis caused by a gene dosage imbalance for Synj1 may contribute to brain dysfunction and cognitive disabilities in Down's syndrome [96]. In addition, mutation analysis of SYNJ1 revealed it as a possible candidate gene for chromosome 21q22-linked bipolar disorder [97].

\section{Acadl Protein}

Long-chain acyl-CoA dehydrogenase (Acadl or LCAD) belongs to the acyl-CoA dehydrogenase family, which is a family of mitochondrial flavoenzymes involved in the first step of long-chain fatty acid $\beta$-oxidation and branched chain amino-acid metabolism. This protein is one of the 4 enzymes that catalyse the initial step of mitochondrial $\beta$-oxidation of straight-chain fatty acid. Defects in this gene are the cause of LCAD deficiency, leading to non-ketotic hypoglycaemia $[98,99]$. Long-chain fatty acids are an important source of energy; however, the role of long-chain fatty acid oxidation in the brain (that does not rely on fat for energy) is poorly understood. Compartmentalization of acyl-CoA dehydrogenases in the human CNS suggests that $\beta$-oxidation in the brain participates in different functions other than generating energy, for example the synthesis and/or degradation of unique cellular lipids and catabolism of aromatic amino acids, compounds that are vital to neuronal function; e.g. it may play a role in the turnover of lipid membrane unsaturated fatty acids that are essential for membrane integrity and structure [100, $101]$.

\section{Sept2 Protein}

As other $\rho$-GTPases $[102,103]$, Sept 2 is crucially involved in modelling neurite outgrowth during neuronal differentiation and a tight regulation of it expression is necessary [104]. Similarly to a number of other proteins that are related to G-protein-signalling pathways, such as Ranbp1, Rin1 and Sept9, p60TRP downregulates Sept2 in the $\mathrm{Cx}$ and Hp during a receptor (e.g. Gria2) resensitisation process. The observation that Sept6 is upregulated in the $\mathrm{Cx}$ might be another spatial brain-region-specific event that needs to be investigated further.

\section{Mtap2 Protein}

Mtap2 regulates and organizes microtubules and may serve as a scaffolding protein for neuromodulatory activities. Neuronal activity-dependent dynamic changes 


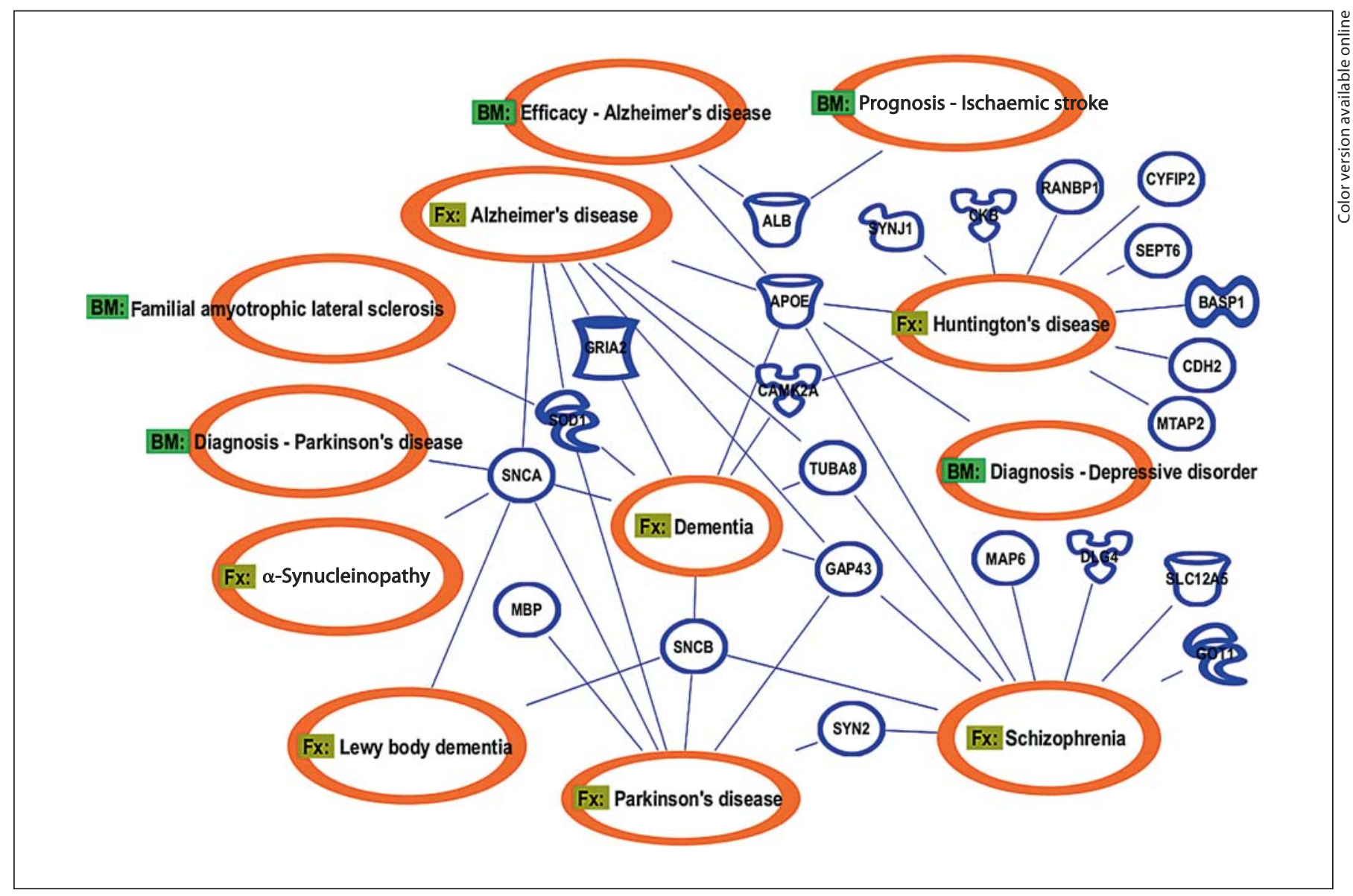

Fig. 9. p60TRP-associated neurological disorders. IPA-based network analysis of iTRAQ-identified proteins of mouse brain $\mathrm{Cx}$ and $\mathrm{Hp}$ exhibits p60TRP-regulated biomarkers (BM) and proteins linked with disease function (Fx). p60TRP directly regulates diagnostic, prognostic and efficacy biomarkers of PD, depressive disorder, ischaemic stroke, familial amyotrophic lateral sclerosis and $\mathrm{AD}$, respectively. of microtubules are important to maintain neuronal morphology and function and are spatial and temporaldependent processes during synaptic plasticity [105]. A spatially and temporally dependent downregulation of indices of dendrites and spines, such as Mtap2, during neurosynaptic plasticity processes has been reported previously [106]. Additionally, a high Mtap2-associated microtubule turnover that accompanies synaptic plasticity and memory formation might be another reason for a temporal/spatial change in Mtap2 levels in the Cx and Hp [107]. Further experiments have also to identify the specific Mtap2 isoforms involved in this mechanism.

\section{Snca Protein}

$\alpha$-Synuclein is a member of the synuclein family, which also includes $\beta$ - and $\gamma$-synuclein. Synucleins are abundantly expressed in the brain and $\alpha$ - and $\beta$-synucleins inhibit phospholipase $\mathrm{D}_{2}$ selectively. Snca may serve to integrate presynaptic signalling and membrane trafficking. Snca is a natively unfolded protein which plays a central role in the control of dopaminergic neuronal functions and which is thought to be critically implicated in PD pathophysiology. Defects in Snca have been implicated in the pathogenesis of PD [108]. PD is characterized by a progressive loss of dopaminergic neurons of the nigrostriatal system and by the presence of Lewy bodies, proteinaceous inclusions mainly composed of filamentous Snca aggregates. Indeed, besides the fact that Snca is the main protein component of Lewy bodies, genetic studies showed that mutations and multiplications of the Snca gene are responsible for the onset of familial forms of PD. A large body of evidence indicates that Snca pa- 
thology at dopaminergic synapses may underlie the onset of neuronal cell dysfunction and degeneration in the PD brain, particularly neurodegeneration caused by presynaptic Snca aggregation $[109,110]$. In addition, abnormalities of Snca and NMDARs are implicated in the pathogenesis of $\mathrm{PD}$ through mechanisms involving oxidative stress and excitotoxicity as Snca may promote clathrinmediated NMDAR endocytosis $[111,112]$ and large Snca oligomers enhance both pre- and post-synaptic AMPARmediated synaptic transmission, thereby aggravating intracellular calcium dyshomeostasis and contributing to excitotoxic nerve cell death in synucleinopathies [113].

In conclusion, neuronal p60TRP overexpression may contribute to improved cognitive functions by promoting synaptic proteins such as Gria2 or Dmxl2 [4]. p60TRP's potential to modulate temporal and spatial brain-sitespecific signalling pathways related to synaptic plasticity and neuroregenerative processes (fig. 9) may thus open new therapeutic avenues for the treatment of various CNS diseases such as $\mathrm{AD}, \mathrm{PD}$, amyotrophic lateral sclerosis, bipolar disorder or schizophrenia.

\section{Acknowledgements}

This study was supported by the Hanyang University and by the Institute of Advanced Studies (Nanyang Technological University).

\section{References}

1 Abu-Helo A, Simonin F: Identification and biological significance of $\mathrm{G}$ protein-coupled receptor associated sorting proteins (GASPs). Pharmacol Ther 2010;126:244-250.

-2 Moser E, Kargl J, Whistler JL, Waldhoer M, Tschische P: G protein-coupled receptorassociated sorting protein 1 regulates the postendocytic sorting of seven-transmembrane-spanning $G$ protein-coupled receptors. Pharmacology 2010;86:22-29.

- 3 Heese K, Yamada T, Akatsu H, Yamamoto T, Kosaka K, Nagai Y, Sawada T: Characterizing the new transcription regulator protein p60TRP. J Cell Biochem 2004;91:1030-1042.

-4 Mishra M, Heese K: p60TRP interferes with the GPCR/secretase pathway to mediate neuronal survival and synaptogenesis. J Cell Mol Med 2011;15:2462-2477.

5 Mishra M, Akatsu H, Heese K: The novel protein mani modulates neurogenesis and neurite-cone growth. J Cell Mol Med 2011; 15:1713-1725.

-6 Mishra M, Manavalan A, Sze SK, Heese K: Neuronal p60TRP expression modulates cardiac capacity. J Proteomics 2012;75:16001617.

-7 Sundaramurthi H, Manavalan A, Ramachandran U, Hu JM, Sze SK, Heese K: Phenotyping of tianma-stimulated differentiated rat neuronal b104 cells by quantitative proteomics. Neurosignals 2012;20:48-60.

8 Shen Y, Inoue N, Heese K: Neurotrophin-4 (NTF4) mediates neurogenesis in mouse embryonic neural stem cells through the inhibition of the signal transducer and activator of transcription-3 (Stat3) and the modulation of the activity of protein kinase B. Cell Mol Neurobiol 2010;30:909-916.
-9 Islam O, Loo TX, Heese K: Brain-derived neurotrophic factor (BDNF) has proliferative effects on neural stem cells through the truncated TRK-B receptor, MAP kinase, AKT, and STAT-3 signaling pathways. Curr Neurovasc Res 2009;6:42-53.

10 Hiller K, Schobert M, Hundertmark C, Jahn D, Munch R: Jvirgel: Calculation of virtual two-dimensional protein gels. Nucleic Acids Res 2003;31:3862-3865.

11 Cheung ZH, Ip NY: The roles of cyclin-dependent kinase 5 in dendrite and synapse development. Biotechnol J 2007;2:949-957.

12 Yang Y, Kim AH, Bonni A: The dynamic ubiquitin ligase duo: Cdh1-APC and Cdc20APC regulate neuronal morphogenesis and connectivity. Curr Opin Neurobiol 2010;20: 92-99.

$\checkmark 13$ Lee HK, Kirkwood A: AMPA receptor regulation during synaptic plasticity in hippocampus and neocortex. Semin Cell Dev Biol 2011;22:514-520.

-14 Ripley B, Otto S, Tiglio K, Williams ME, Ghosh A: Regulation of synaptic stability by AMPA receptor reverse signaling. Proc Natl Acad Sci USA 2011;108:367-372.

15 Corti C, Xuereb JH, Crepaldi L, Corsi M, Michielin F, Ferraguti F: Altered levels of glutamatergic receptors and $\mathrm{Na}^{+} / \mathrm{K}^{+}$ATPasealphal in the prefrontal cortex of subjects with schizophrenia. Schizophr Res 2011;128: 7-14.

16 Carney DS, Davies BA, Horazdovsky BF: Vps9 domain-containing proteins: activators of Rab5 GTPases from yeast to neurons. Trends Cell Biol 2006;16:27-35.

17 Galvis A, Giambini H, Villasana Z, Barbieri MA: Functional determinants of Ras interference 1 mutants required for their inhbitory activity on endocytosis. Exp Cell Res 2009;315:820-835.
18 Galvis A, Balmaceda V, Giambini H, Conde A, Villasana Z, Fornes MW, Barbieri MA: Inhibition of early endosome fusion by Rab5-binding defective Ras interference 1 mutants. Arch Biochem Biophys 2009;482: 83-95.

19 Kong C, Su X, Chen PI, Stahl PD: Rinl interacts with signal-transducing adaptor molecule (STAM) and mediates epidermal growth factor receptor trafficking and degradation. J Biol Chem 2007;282:15294-15301.

20 Bliss JM, Gray EE, Dhaka A, O’Dell TJ, Colicelli J: Fear learning and extinction are linked to neuronal plasticity through Rin 1 signaling. J Neurosci Res 2010;88:917-926.

21 Dzudzor B, Huynh L, Thai M, Bliss JM, Nagaoka Y, Wang Y, Ch'ng TH, Jiang M, Martin KC, Colicelli J: Regulated expression of the Ras effector Rin1 in forebrain neurons. Mol Cell Neurosci 2010;43:108-116.

22 Wang Y, Waldron RT, Dhaka A, Patel A, Riley MM, Rozengurt E, Colicelli J: The Ras effector Rin1 directly competes with Raf and is regulated by 14-3-3 proteins. Mol Cell Biol 2002;22:916-926.

-23 Dhaka A, Costa RM, Hu H, Irvin DK, Patel A, Kornblum HI, Silva AJ, O'Dell TJ, Colicelli J: The Ras effector Rin1 modulates the formation of aversive memories. J Neurosci 2003;23:748-757.

24 Deininger K, Eder M, Kramer ER, Zieglgansberger W, Dodt HU, Dornmair K, Colicelli J, Klein R: The Rab5 guanylate exchange factor Rin1 regulates endocytosis of the EphA4 receptor in mature excitatory neurons. Proc Natl Acad Sci USA 2008;105:12539-12544. 
-25 Kawabe H, Sakisaka T, Yasumi M, Shingai T, Izumi G, Nagano F, Deguchi-Tawarada M, Takeuchi M, Nakanishi H, Takai Y: A novel rabconnectin-3-binding protein that directly binds a GDP/GTP exchange protein for Rab3A small $\mathrm{G}$ protein implicated in $\mathrm{Ca}(2+)$ dependent exocytosis of neurotransmitter. Genes Cells 2003;8:537-546.

-26 Nagano F, Kawabe H, Nakanishi H, Shinohara M, Deguchi-Tawarada M, Takeuchi M, Sasaki T, Takai Y: Rabconnectin-3, a novel protein that binds both GDP/GTP exchange protein and GTPase-activating protein for Rab3 small G protein family. J Biol Chem 2002;277:9629-9632.

-27 Sethi N, Yan Y, Quek D, Schupbach T, Kang $Y$ : Rabconnectin-3 is a functional regulator of mammalian notch signaling. J Biol Chem 2010;285:34757-34764.

28 Kageyama R, Niwa Y, Shimojo H: Rhythmic gene expression in somite formation and neural development. Mol Cells 2009;27:497502.

-29 Zhu X, Zhang J, Tollkuhn J, Ohsawa R, Bresnick EH, Guillemot F, Kageyama R, Rosenfeld MG: Sustained notch signaling in progenitors is required for sequential emergence of distinct cell lineages during organogenesis. Genes Dev 2006;20:2739-2753.

-30 Mosevitsky MI, Capony JP, Skladchikova G, Novitskaya VA, Plekhanov A, Zakharov VV: The BASP1 family of myristoylated proteins abundant in axonal termini. Primary structure analysis and physico-chemical properties. Biochimie 1997;79:373-384.

- 31 Behan AT, Byrne C, Dunn MJ, Cagney G, Cotter DR: Proteomic analysis of membrane microdomain-associated proteins in the dorsolateral prefrontal cortex in schizophrenia and bipolar disorder reveals alterations in LAMP, STXB1 and BASP1 protein expression. Mol Psychiatry 2009;14:601-613.

- 32 Anwar S, Peters O, Millership S, Ninkina N, Doig N, Connor-Robson N, Threlfell S, Kooner G, Deacon RM, Bannerman DM, Bolam JP, Chandra SS, Cragg SJ, Wade-Martins R, Buchman VL: Functional alterations to the nigrostriatal system in mice lacking all three members of the synuclein family. J Neurosci 2011;31:7264-7274.

- 33 Varkey J, Isas JM, Mizuno N, Jensen MB, Bhatia VK, Jao CC, Petrlova J, Voss JC, Stamou DG, Steven AC, Langen R: Membrane curvature induction and tubulation are common features of synucleins and apolipoproteins. J Biol Chem 2010;285:3248632493.

- 34 Beyer K, Ispierto L, Latorre P, Tolosa E, Ariza A: Alpha- and beta-synuclein expression in Parkinson disease with and without dementia. J Neurol Sci 2011;310:112-117.

- 35 Beyer K, Munoz-Marmol AM, Sanz C, Marginet-Flinch R, Ferrer I, Ariza A: New brainspecific beta-synuclein isoforms show expression ratio changes in Lewy body diseases. Neurogenetics 2012;13:61-72.
Shaltiel-Karyo R, Frenkel-Pinter M, EgozMatia N, Frydman-Marom A, Shalev DE, Segal D, Gazit E: Inhibiting alpha-synuclein oligomerization by stable cell-penetrating beta-synuclein fragments recovers phenotype of Parkinson's disease model flies. PLoS One 2010;5:e13863.

-37 Ide M, Lewis DA: Altered cortical CDC42 signaling pathways in schizophrenia: implications for dendritic spine deficits. Biol Psychiatry 2010;68:25-32.

38 Spiliotis ET: Regulation of microtubule organization and functions by septin GTPases. Cytoskeleton (Hoboken) 2010;67:339-345.

- 39 Ito H, Atsuzawa K, Morishita R, Usuda N, Sudo K, Iwamoto I, Mizutani K, Katoh-Semba R, Nozawa Y, Asano T, Nagata K: Sept8 controls the binding of vesicle-associated membrane protein 2 to synaptophysin. J Neurochem 2009;108:867-880.

40 Peterson EA, Petty EM: Conquering the complex world of human septins: implications for health and disease. Clin Genet 2010; 77:511-524.

41 Hall PA, Russell SE: The pathobiology of the septin gene family. J Pathol 2004;204:489505.

42 Roeseler S, Sandrock K, Bartsch I, Zieger B: Septins, a novel group of GTP-binding proteins: relevance in hemostasis, neuropathology and oncogenesis. Klin Pädiatr 2009;221: 150-155.

-43 Tsang CW, Estey MP, DiCiccio JE, Xie H, Patterson D, Trimble WS: Characterization of presynaptic septin complexes in mammalian hippocampal neurons. Biol Chem 2011; 392:739-749.

44 Buser AM, Erne B, Werner HB, Nave KA, Schaeren-Wiemers N: The septin cytoskeleton in myelinating glia. Mol Cell Neurosci 2009;40:156-166.

45 Ludwig A, Uvarov P, Soni S, Thomas-Crusells J, Airaksinen MS, Rivera C: Early growth response 4 mediates $\mathrm{BDNF}$ induction of potassium chloride cotransporter 2 transcription. J Neurosci 2011;31:644-649.

46 Horn Z, Ringstedt T, Blaesse P, Kaila K, Herlenius E: Premature expression of KCC2 in embryonic mice perturbs neural development by an ion transport-independent mechanism. Eur J Neurosci 2010;31:21422155.

47 Yacoubian TA, Slone SR, Harrington AJ, Hamamichi S, Schieltz JM, Caldwell KA, Caldwell GA, Standaert DG: Differential neuroprotective effects of 14-3-3 proteins in models of Parkinson's disease. Cell Death Dis 2010;1:e2.

48 Li X, Wang QJ, Pan N, Lee S, Zhao Y, Chait BT, Yue Z: Phosphorylation-dependent 14-33 binding to LRRK2 is impaired by common mutations of familial Parkinson's disease. PLoS One 2011;6:e17153.

49 Radhakrishnan VM, Martinez JD: 14-3-3 gamma induces oncogenic transformation by stimulating MAP kinase and PI3K signaling. PLoS One 2010;5:e11433.
50 McFarland MA, Ellis CE, Markey SP, Nussbaum RL: Proteomics analysis identifies phosphorylation-dependent alpha-synuclein protein interactions. Mol Cell Proteomics 2008;7:2123-2137.

51 Lee CM, Stevens LA, Hsu HC, Tsai SC, Lee YT, Moss J, Vaughan M: Expression in human endothelial cells of ADP-ribosylation factors, 20-kDa guanine nucleotide-binding proteins involved in the initiation of vesicular transport. J Mol Cell Cardiol 1996;28: 1911-1920.

52 Cockcroft S, Thomas GM, Fensome A, Geny B, Cunningham E, Gout I, Hiles I, Totty NF, Truong O, Hsuan JJ: Phospholipase D: a downstream effector of ARF in granulocytes. Science 1994;263:523-526.

53 Suzuki I, Owada Y, Suzuki R, Yoshimoto T, Kondo $\mathrm{H}$ : Localization of mRNAs for six ARFs (ADP-ribosylation factors) in the brain of developing and adult rats and changes in the expression in the hypoglossal nucleus after its axotomy. Brain Res Mol Brain Res 2001;88:124-134.

54 Braun A, Breuss M, Salzer MC, Flint J, Cowan NJ, Keays DA: Tuba8 is expressed at low levels in the developing mouse and human brain. Am J Hum Genet 2010;86:819-822, author reply $822-813$.

55 Vazquez-Higuera JL, Mateo I, Sanchez-Juan P, Rodriguez-Rodriguez E, Pozueta A, Calero M, Dobato JL, Frank-Garcia A, Valdivieso F, Berciano J, Bullido MJ, Combarros O: Genetic variation in the tau protein phosphatase-2a pathway is not associated with Alzheimer's disease risk. BMC Res Notes 2011; 4:327.

56 Rekart JL, Routtenberg A: Overexpression of GAP-43 reveals unexpected properties of hippocampal mossy fibers. Hippocampus 2010;20:46-57.

-57 Foscarin S, Gianola S, Carulli D, Fazzari P, Mi S, Tamagnone L, Rossi F: Overexpression of GAP-43 modifies the distribution of the receptors for myelin-associated growth-inhibitory proteins in injured Purkinje axons. Eur J Neurosci 2009;30:1837-1848.

58 Hannappel E, Huff T: The thymosins. Prothymosin alpha, parathymosin, and betathymosins: structure and function. Vitam Horm 2003;66:257-296.

59 Martic G, Karetsou Z, Kefala K, Politou AS, Clapier CR, Straub T, Papamarcaki T: Parathymosin affects the binding of linker histone $\mathrm{H} 1$ to nucleosomes and remodels chromatin structure. J Biol Chem 2005;280: 16143-16150.

60 Doyle GA, Dahl JP, Bloch PJ, Weller AE, Lohoff FW, Ferraro TN, Berrettini WH: Association study of polymorphisms in the autosomal mitochondrial complex I subunit gene, NADH dehydrogenase (ubiquinone) flavoprotein 2, and bipolar disorder. Psychiatr Genet 2011;21:51-52. 
61 Zhang W, Chen X, Gong W, Tang J, Tan L, Guo H, Yao YG: Common promoter variants of the NDUVF2 gene do not confer susceptibility to schizophrenia in Han chinese. Behav Brain Funct 2010;6:75.

-62 Nishioka K, Vilarino-Guell C, Cobb SA, Kachergus JM, Ross OA, Hentati E, Hentati F, Farrer MJ: Genetic variation of the mitochondrial complex I subunit NDUFV2 and Parkinson's disease. Parkinsonism Relat Disord 2010;16:686-687.

63 Washizuka S, Iwamoto K, Kakiuchi C, Bundo M, Kato T: Expression of mitochondrial complex I subunit gene NDUVF2 in the lymphoblastoid cells derived from patients with bipolar disorder and schizophrenia. Neurosci Res 2009;63:199-204.

-64 Martins-de-Souza D, Gattaz WF, Schmitt A, Rewerts C, Maccarrone G, Dias-Neto E, Turck CW: Prefrontal cortex shotgun proteome analysis reveals altered calcium homeostasis and immune system imbalance in schizophrenia. Eur Arch Psychiatry Clin Neurosci 2009;259:151-163.

-65 Martins-de-Souza D, Gattaz WF, Schmitt A, Rewerts C, Marangoni S, Novello JC, Maccarrone G, Turck CW, Dias-Neto E: Alterations in oligodendrocyte proteins, calcium homeostasis and new potential markers in schizophrenia anterior temporal lobe are revealed by shotgun proteome analysis. J Neural Transm 2009;116:275-289.

-66 Mizuta I, Tsunoda T, Satake W, Nakabayashi Y, Watanabe M, Takeda A, Hasegawa K, Nakashima K, Yamamoto M, Hattori N, Murata M, Toda T: Calbindin 1, fibroblast growth factor 20, and alpha-synuclein in sporadic Parkinson's disease. Hum Genet 2008;124: 89-94.

-67 Silverman JB, Restituito S, Lu W, Lee-Edwards L, Khatri L, Ziff EB: Synaptic anchorage of AMPA receptors by cadherins through neural plakophilin-related ARM protein AMPA receptor-binding protein complexes. J Neurosci 2007;27:8505-8516.

68 Zhang J, Petit CM, King DS, Lee AL: Phosphorylation of a PDZ domain extension modulates binding affinity and interdomain interactions in postsynaptic density-95 (PSD-95) protein, a membrane-associated guanylate kinase (MAGUK). J Biol Chem 2011;286:41776-41785.

69 Gottschalk M, Bach A, Hansen JL, Krogsgaard-Larsen P, Kristensen AS, Stromgaard $\mathrm{K}$ : Detecting protein-protein interactions in living cells: development of a bioluminescence resonance energy transfer assay to evaluate the PSD-95/NMDA receptor interaction. Neurochem Res 2009;34:1729-1737.

70 Gardoni F: MAGUK proteins: new targets for pharmacological intervention in the glutamatergic synapse. Eur J Pharmacol 2008; 585:147-152.
71 Cousins SL, Papadakis M, Rutter AR, Stephenson FA: Differential interaction of NMDA receptor subtypes with the post-synaptic density- 95 family of membrane associated guanylate kinase proteins. J Neurochem 2008;104:903-913.

72 Funk AJ, Rumbaugh G, Harotunian V, McCullumsmith RE, Meador-Woodruff JH: Decreased expression of NMDA receptorassociated proteins in frontal cortex of elderly patients with schizophrenia. Neuroreport 2009;20:1019-1022.

73 Sultana R, Banks WA, Butterfield DA: Decreased levels of PSD95 and two associated proteins and increased levels of BCL2 and caspase 3 in hippocampus from subjects with amnestic mild cognitive impairment: insights into their potential roles for loss of synapses and memory, accumulation of abeta, and neurodegeneration in a prodromal stage of Alzheimer's disease. J Neurosci Res 2010;88:469-477.

74 Proctor DT, Coulson EJ, Dodd PR: Reduction in post-synaptic scaffolding PSD-95 and SAP-102 protein levels in the Alzheimer inferior temporal cortex is correlated with disease pathology. J Alzheimers Dis 2010;21: 795-811.

75 Leuba G, Savioz A, Vernay A, Carnal B, Kraftsik R, Tardif E, Riederer I, Riederer BM: Differential changes in synaptic proteins in the Alzheimer frontal cortex with marked increase in PSD-95 postsynaptic protein. J Alzheimers Dis 2008;15:139-151.

76 Yoshii A, Murata Y, Kim J, Zhang C, Shokat KM, Constantine-Paton M: Trkb and protein kinase Mzeta regulate synaptic localization of PSD-95 in developing cortex. J Neurosci 2011;31:11894-11904.

77 Molnar E: Long-term potentiation in cultured hippocampal neurons. Semin Cell Dev Biol 2011;22:506-513.

78 Kolarow R, Brigadski T, Lessmann V: Postsynaptic secretion of BDNF and NT-3 from hippocampal neurons depends on calcium calmodulin kinase II signaling and proceeds via delayed fusion pore opening. J Neurosci 2007:27:10350-10364

79 Yamasaki N, Maekawa M, Kobayashi K, Kajii Y, Maeda J, Soma M, Takao K, Tanda K, Ohira K, Toyama K, Kanzaki K, Fukunaga K, Sudo Y, Ichinose H, Ikeda M, Iwata N, Ozaki N, Suzuki H, Higuchi M, Suhara T, Yuasa S, Miyakawa T: Alpha-CAMKII deficiency causes immature dentate gyrus, a novel candidate endophenotype of psychiatric disorders. Mol Brain 2008;1:6.

80 Hegde AN: The ubiquitin-proteasome pathway and synaptic plasticity. Learn Mem 2010;17:314-327.

81 Djakovic SN, Schwarz LA, Barylko B, DeMartino GN, Patrick GN: Regulation of the proteasome by neuronal activity and calcium/calmodulin-dependent protein kinase II. J Biol Chem 2009;284:26655-26665.
82 Fitzgerald PJ: The NMDA receptor may participate in widespread suppression of circuit level neural activity, in addition to a similarly prominent role in circuit level activation. Behav Brain Res 2012;230:291-298.

83 Lau A, Tymianski M: Glutamate receptors, neurotoxicity and neurodegeneration. Pflugers Arch 2010;460:525-542.

84 Wang Y, Qin ZH: Molecular and cellular mechanisms of excitotoxic neuronal death. Apoptosis 2010;15:1382-1402.

85 Zhang XM, Zhu J: Kainic acid-induced neurotoxicity: targeting glial responses and gliaderived cytokines. Curr Neuropharmacol 2011;9:388-398.

-86 Carri MT, Cozzolino M: Sod1 and mitochondria in ALS: a dangerous liaison. J Bioenerg Biomembr 2011;43:593-599.

87 Contestabile A: Amyotrophic lateral sclerosis: from research to therapeutic attempts and therapeutic perspectives. Curr Med Chem 2011;18:5655-5665.

-88 Atlante A, Calissano P, Bobba A, Giannattasio S, Marra E, Passarella S: Glutamate neurotoxicity, oxidative stress and mitochondria. FEBS Lett 2001;497:1-5.

89 Sandrock K, Bartsch I, Blaser S, Busse A Busse E, Zieger B: Characterization of human septin interactions. Biol Chem 2011; 392:751-761.

90 Sudo K, Ito H, Iwamoto I, Morishita R, Asano T, Nagata K: SEPT9 sequence alternations causing hereditary neuralgic amyotrophy are associated with altered interactions with SEPT4/SEPT11 and resistance to Rho/Rhotekin-signaling. Hum Mutat 2007;28:10051013.

-91 Hannibal MC, Ruzzo EK, Miller LR, Betz B Buchan JG, Knutzen DM, Barnett K, Landsverk ML, Brice A, LeGuern E, Bedford HM, Worrall BB, Lovitt S, Appel SH, Andermann E, Bird TD, Chance PF: SEPT9 gene sequencing analysis reveals recurrent mutations in hereditary neuralgic amyotrophy. Neurology 2009;72:1755-1759.

92 Kuhlenbaumer G, Hannibal MC, Nelis E, Schirmacher A, Verpoorten N, Meuleman J, Watts GD, De Vriendt E, Young P, Stogbauer F, Halfter H, Irobi J, Goossens D, Del-Favero J, Betz BG, Hor H, Kurlemann G, Bird TD, Airaksinen E, Mononen T, Serradell AP, Prats JM, Van Broeckhoven C, De Jonghe P, Timmerman V, Ringelstein EB, Chance PF: Mutations in SEPT9 cause hereditary neuralgic amyotrophy. Nat Genet 2005;37:10441046.

93 Storlazzi CT, Brekke HR, Mandahl N, Brosjo O, Smeland S, Lothe RA, Mertens F: Identification of a novel amplicon at distal 17q containing the BIRC5/survivin gene in malignant peripheral nerve sheath tumours. J Pathol 2006;209:492-500. 
-94 Woscholski R, Finan PM, Radley E, Totty NF, Sterling AE, Hsuan JJ, Waterfield MD, Parker PJ: Synaptojanin is the major constitutively active phosphatidylinositol-3,4,5trisphosphate 5-phosphatase in rodent brain. J Biol Chem 1997;272:9625-9628.

95 Lee SY, Wenk MR, Kim Y, Nairn AC, De Camilli P: Regulation of synaptojanin 1 by cyclin-dependent kinase 5 at synapses. Proc Natl Acad Sci USA 2004;101:546-551.

-96 Voronov SV, Frere SG, Giovedi S, Pollina EA, Borel C, Zhang H, Schmidt C, Akeson EC, Wenk MR, Cimasoni L, Arancio O, Davisson MT, Antonarakis SE, Gardiner K, De Camilli P, Di Paolo G: Synaptojanin 1-linked phosphoinositide dyshomeostasis and cognitive deficits in mouse models of Down's syndrome. Proc Natl Acad Sci USA 2008; 105: 9415-9420.

-97 Saito T, Guan F, Papolos DF, Lau S, Klein M, Fann CS, Lachman HM: Mutation analysis of SYNJ1: a possible candidate gene for chromosome 21q22-linked bipolar disorder. Mol Psychiatry 2001;6:387-395.

98 Lea W, Abbas AS, Sprecher H, Vockley J, Schulz H: Long-chain acyl-CoA dehydrogenase is a key enzyme in the mitochondrial beta-oxidation of unsaturated fatty acids. Biochim Biophys Acta 2000;1485:121128.

-99 Treem WR, Stanley CA, Hale DE, Leopold HB, Hyams JS: Hypoglycemia, hypotonia, and cardiomyopathy: the evolving clinical picture of long-chain acyl-CoA dehydrogenase deficiency. Pediatrics 1991;87:328333.
100 He M, Pei Z, Mohsen AW, Watkins P, Murdoch G, Van Veldhoven PP, Ensenauer R, Vockley J: Identification and characterization of new long chain acyl-CoA dehydrogenases. Mol Genet Metab 2011;102:418429.

101 Ensenauer R, He M, Willard JM, Goetzman ES, Corydon TJ, Vandahl BB, Mohsen AW, Isaya G, Vockley J: Human acyl-CoA dehydrogenase-9 plays a novel role in the mitochondrial beta-oxidation of unsaturated fatty acids. J Biol Chem 2005;280:3230932316.

102 Luo L: Rho GTPases in neuronal morphogenesis. Nat Rev Neurosci 2000;1:173-180.

103 Hirose M, Ishizaki T, Watanabe N, Uehata M, Kranenburg O, Moolenaar WH, Matsumura F, Maekawa M, Bito H, Narumiya S: Molecular dissection of the Rho-associated protein kinase (p160ROCK)-regulated neurite remodeling in neuroblastoma N1E115 cells. J Cell Biol 1998;141:1625-1636.

104 Vega IE, Hsu SC: The septin protein Nedd5 associates with both the exocyst complex and microtubules and disruption of its GTPase activity promotes aberrant neurite sprouting in PC12 cells. Neuroreport 2003; 14:31-37.

105 Kapitein LC, Yau KW, Gouveia SM, van der Zwan WA, Wulf PS, Keijzer N, Demmers J, Jaworski J, Akhmanova A, Hoogenraad CC: NMDA receptor activation suppresses microtubule growth and spine entry. J Neurosci 2011;31:8194-8209.

106 Webster MJ, Elashoff M, Weickert CS: Molecular evidence that cortical synaptic growth predominates during the first decade of life in humans. Int J Dev Neurosci 2011;29:225-236.
07 Fanara P, Husted KH, Selle K, Wong PY, Banerjee J, Brandt R, Hellerstein MK: Changes in microtubule turnover accompany synaptic plasticity and memory formation in response to contextual fear conditioning in mice. Neuroscience 2010;168:167-178.

108 Bellucci A, Navarria L, Zaltieri M, Missale C, Spano P: Alpha-synuclein synaptic pathology and its implications in the development of novel therapeutic approaches to cure Parkinson's disease. Brain Res 2012; 1432:95-113.

109 Schulz-Schaeffer WJ: The synaptic pathology of alpha-synuclein aggregation in dementia with Lewy bodies, Parkinson's disease and Parkinson's disease dementia. Acta Neuropathol 2010;120:131-143.

110 Yasuda T, Mochizuki H: The regulatory role of alpha-synuclein and parkin in neuronal cell apoptosis: possible implications for the pathogenesis of Parkinson's disease. Apoptosis 2010;15:1312-1321.

111 Cheng F, Li X, Li Y, Wang C, Wang T, Liu G, Baskys A, Ueda K, Chan P, Yu S: Alphasynuclein promotes clathrin-mediated NMDA receptor endocytosis and attenuates NMDA-induced dopaminergic cell death. J Neurochem 2011;119:815-825.

112 Sherer TB, Betarbet R, Greenamyre JT: Pathogenesis of Parkinson's disease. Curr Opin Investig Drugs 2001;2:657-662.

113 Huls S, Hogen T, Vassallo N, Danzer KM, Hengerer B, Giese A, Herms J: AMPA-receptor-mediated excitatory synaptic transmission is enhanced by iron-induced alpha-synuclein oligomers. J Neurochem 2011;117:868-878. 